Key Words: Tritium, concrete rubble, diffusion, transport annual flux,

Retention: Permanent

\title{
Estimation of Tritium Annual Flux From Concrete Rubble Buried in the E-Area Slit Trenches (U)
}

\author{
Thong Hang, Daniel I. Kaplan, and Kimberly R. Powell \\ Westinghouse Savannah River Company
}

August 27, 2004

Westinghouse Savannah River Company

Savannah River Site

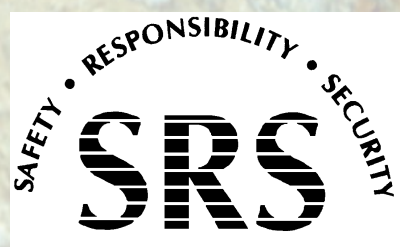

Aiken, SC 29808 
This document was prepared in conjunction with work accomplished under Contract No. DE-AC09-96SR18500 with the U. S. Department of Energy.

\section{DISCLAIMER}

This report was prepared as an account of work sponsored by an agency of the United States Government. Neither the United States Government nor any agency thereof, nor any of their employees, makes any warranty, express or implied, or assumes any legal liability or responsibility for the accuracy, completeness, or usefulness of any information, apparatus, product or process disclosed, or represents that its use would not infringe privately owned rights. Reference herein to any specific commercial product, process or service by trade name, trademark, manufacturer, or otherwise does not necessarily constitute or imply its endorsement, recommendation, or favoring by the United States Government or any agency thereof. The views and opinions of authors expressed herein do not necessarily state or reflect those of the United States Government or any agency thereof.

This report has been reproduced directly from the best available copy.

Available for sale to the public, in paper, from: U.S. Department of Commerce, National Technical Information Service, 5285 Port Royal Road, Springfield, VA 22161, phone: (800) 553-6847, fax: (703) 605-6900

email: orders@ntis.fedworld.gov

online ordering: http://www.ntis.gov/help/index.asp

Available electronically at http://www.osti.gov/bridge

Available for a processing fee to U.S. Department of Energy and its contractors, in paper, from: U.S. Department of Energy, Office of Scientific and Technical Information, P.O. Box 62, Oak Ridge, TN 37831-0062,

phone: (865)576-8401,

fax: (865)576-5728

email: $\underline{\text { reports@ adonis.osti.gov }}$ 
Key Words: Tritium, concrete rubble, diffusion, transport annual flux,

Retention: Permanent

\title{
Estimation of Tritium Annual Flux From Concrete Rubble Buried in the E-Area Slit Trenches $(U)$
}

\author{
Thong Hang, Daniel I. Kaplan, and Kimberly R. Powell \\ Westinghouse Savannah River Company
}

August 27, 2004

Westinghouse Savannah River Company

Savannah River Site

Aiken, SC 29808

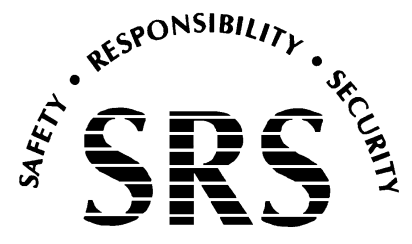

SAVANNAH RIVER SITE

Prepared for the U.S. Department of Energy Under

Contract Number DE-AC09-96SR18500 
This page was intentionally left blank 


\section{TABLE OF CONTENTS}

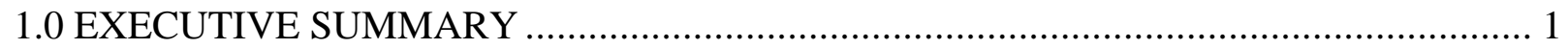

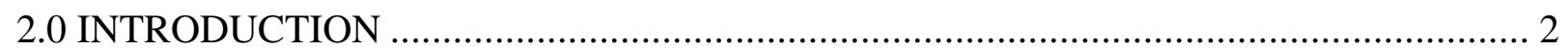

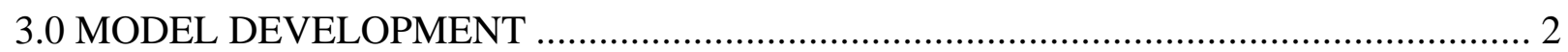

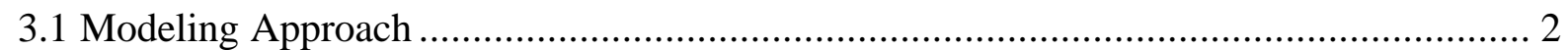

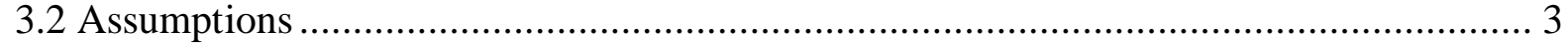

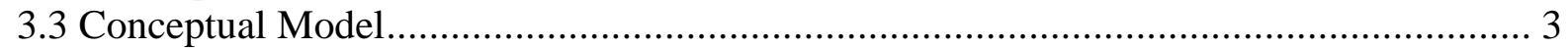

4.0 ESTIMATION OF CONCRETE RUBBLE SIZE DISTRIBUTION ............................ 7

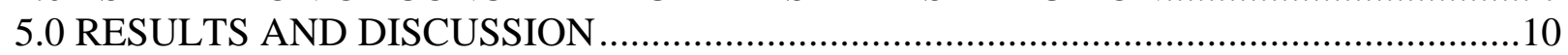

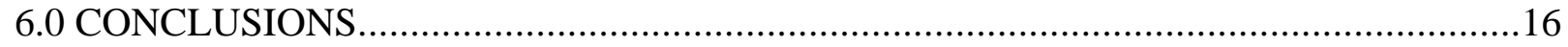

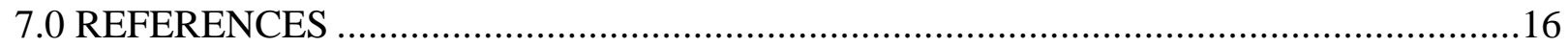

8.0 APPENDIX A: Estimation of Concrete Rubble Size Distribution................................... 17

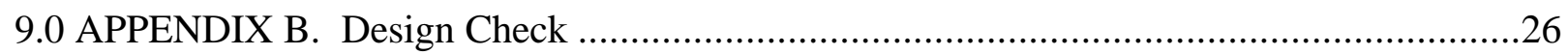




\section{LIST OF FIGURES}

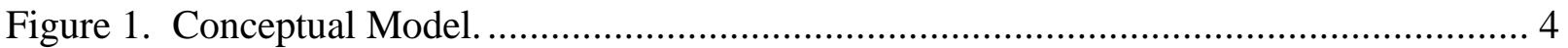

Figure 2. Modeling Grid. ........................................................................................... 5

Figure 3. $2 \mathrm{~cm}$ x $1 \mathrm{~cm}$ Concrete Waste Block..................................................................... 5

Figure 4. Flow Simulation of $2 \mathrm{~cm} x 1 \mathrm{~cm}$ Concrete Waste Block....................................... 6

Figure 5. Concrete Rubble Pile at the $\mathrm{C}$ and D Landfill. .............................................. 7

Figure 6. $3 \mathrm{ft}$ X $3 \mathrm{ft}$ Study Area with Smaller Concrete Rubble Mixed with Soil. .................. 8

Figure 7. Fractional Flux of $3 \mathrm{H}(0.4 \mathrm{~cm} \times 0.2 \mathrm{~cm}$ Concrete Waste Block; Initial Inventory: $1 \mathrm{Ci}$;

Concrete Molecular Diffusivity: $\left.5 \mathrm{E}-8 \mathrm{~cm}^{2} / \mathrm{s}\right)$. 10

Figure 8. Fractional Flux of ${ }^{3} \mathrm{H}(1.2 \mathrm{~cm} \times 0.6 \mathrm{~cm}$ Concrete Waste Block; Initial Inventory: $1 \mathrm{Ci}$;

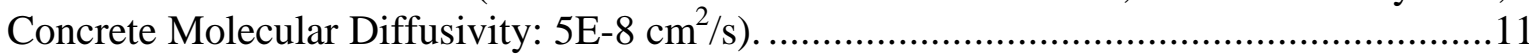

Figure 9. Fractional Flux of ${ }^{3} \mathrm{H}(2 \mathrm{~cm} \times 1 \mathrm{~cm}$ Concrete Waste Block; Initial Inventory: 1Ci;

Concrete Molecular Diffusivity: $\left.5 \mathrm{E}-8 \mathrm{~cm}^{2} / \mathrm{s}\right)$.

Figure 10. Fractional Flux for ${ }^{3} \mathrm{H}(16 \mathrm{~cm}$ x $8 \mathrm{~cm}$ Concrete Waste Block; Initial Inventory: 1Ci;

Concrete Molecular Diffusivity: $\left.5 \mathrm{E}-8 \mathrm{~cm}^{2} / \mathrm{s}\right)$.

Figure 11. Fractional Flux of ${ }^{3} \mathrm{H}(60 \mathrm{~cm} \times 30 \mathrm{~cm}$ Concrete Waste Block; Initial Inventory: $1 \mathrm{Ci}$;

Concrete Molecular Diffusivity: $\left.5 \mathrm{E}-8 \mathrm{~cm}^{2} / \mathrm{s}\right)$.

Figure 12. Composite Fractional Flux of ${ }^{3} \mathrm{H}$ for the Best-Estimate Block Size Distribution and the Small Block Size Distribution (Initial Inventory: 1Ci; Concrete Molecular Diffusivity:

$\left.5 \mathrm{E}-8 \mathrm{~cm}^{2} / \mathrm{s}\right)$.

Figure 13. Cumulative Loss of ${ }^{3} \mathrm{H}$ from Concrete Blocks with the Best-Estimate Size

Distribution (Initial Inventory: 1Ci; Concrete Molecular Diffusivity: $5 \mathrm{E}-8 \mathrm{~cm}^{2} / \mathrm{s}$; SumFlux

- Lost Due to Transport Only; SumDecay - Lost Due to Decay Only; SumFlux+Decay -

Lost Due to Decay + Transport)

Figure 14. Cumulative Loss of ${ }^{3} \mathrm{H}$ from Concrete Blocks with a Small Block Size Distribution

(Initial Inventory: 1Ci; Concrete Molecular Diffusivity: $5 \mathrm{E}-8 \mathrm{~cm}^{2} / \mathrm{s}$; SumFlux - Lost Due

to Transport Only; SumDecay - Lost Due to Decay Only; SumFlux+Decay - Lost Due to

Decay + Transport)

\section{LIST OF TABLES}

Table 1. Model Input Values for Materials. 6

Table 2. Best-Estimate Particle Size Distribution of Concrete in the $10 \mathrm{ft}$ X $20 \mathrm{ft}$ Study Area. 9

Table 3. Small Block Particle Size Distribution Within the $3 \mathrm{ft}$ X $3 \mathrm{ft}$ Study Area. 9 


\subsection{EXECUTIVE SUMMARY}

Some of the concrete rubble generated from the demolition and destruction of SRS facilities contains tritium. The tritium-bearing rubble will be disposed in the E-Area slit trenches. In the past, it was assumed for Performance Assessment (risk) modeling that tritium leached from concrete as if the tritium existed entirely on the concrete surfaces. Although conservative (overestimates risk associated with the groundwater pathway), this assumption does not account for the slow diffusion of tritium from the inside to the outside of the concrete rubble. The objective of this modeling study was to include the diffusion process in tritium annual flux calculations for use in future Special Analyses or Performance Assessments involving the concrete rubble. Our approach was to 1) calculate tritium diffusion, dispersion, and advective transport within and external to particles of varying size, 2) assume a particle size distribution of the concrete rubble based on measurements taken of an existing rubble pile, and 3) calculate an annual fractional flux of tritium (in units of $\mathrm{Ci} / \mathrm{yr} \cdot \mathrm{Ci}$ ) from the hypothetical rubble to the underlying aquifer. Annual fractional flux values provide modelers the flexibility to vary the tritium inventory for the scenario of interest.

Simulations showed that for the best-estimate of concrete block size distribution that $\sim 90 \%$ of the tritium either decayed or was transported (diffusion and advection) from the concrete rubble within 20 years. Of this $90 \%$ tritium loss, about 50\% was due to transport, whereas the remaining $40 \%$ was due to decay. Loss due to transport was more important during the initial 10 years; afterwards, the two processes were equally important for controlling tritium concentrations. When the tritium was assumed to exist entirely on the concrete surfaces, as was the case in the original conceptual model, all the tritium was transported from the concrete within a year.

This report provides a first approximation quantifying tritium diffusion from concrete particles into groundwater. Additional work needs to be directed at quantifying the block size distribution of tritium-containing concrete rubble, the influence of inter-block interactions on diffusion processes, and uneven distribution of tritium within concrete rubble blocks. 


\subsection{INTRODUCTION}

A growing amount of concrete containing tritium is being generated as a result of ongoing demolition and destruction activities on the SRS. To assist in determining how much radioactive low level waste (such as the tritiated concrete) can be safely disposed, performance assessments are conducted. In the past, these calculations assumed that all the tritium associated with buried concrete existed on the exterior concrete surfaces. Although this is a conservative assumption with respect to the groundwater pathway, it is not accurate.

The objective of this study was to more accurately model tritium release from concrete rubble. Particular attention was directed at incorporating tritium diffusion from the concrete rubble into the surrounding groundwater.

\subsection{MODEL DEVELOPMENT}

\subsection{MODELING APPROACH}

PC-based PORFLOWTM Version 5.96 (Analytic \& Computational Research, Inc.) was used in these simulations. PORFLOW ${ }^{\mathrm{TM}}$ solves problems involving transient and steadystate fluid flow, heat and mass transport in multi-phase, variable saturation conditions, porous or fractured media flow, and dynamic changes in phases. The porous/fractured media may be anisotropic and heterogeneous. Arbitrary sources (injection or pumping wells) may be present, and chemical reactions or radioactive decay may take place in the model. PORFLOW ${ }^{\mathrm{TM}}$ has been widely used at the SRS and in the DOE complex to address major issues related to the ground water and radioactive waste management.

The governing mass transport equation of species $k$ in the fluid phase is given by equation 1:

$$
\frac{\partial C_{k}}{\partial t}+\frac{\partial}{\partial x_{i}}\left(V_{i} C_{k}\right)=\frac{\partial}{\partial x_{i}}\left(D_{i j} \frac{\partial C_{k}}{\partial x_{j}}\right)+S_{k}+\gamma_{k}
$$

$\mathrm{C}_{\mathrm{k}} \quad$ Concentration of species $k$

$\mathrm{V}_{\mathrm{i}} \quad$ Fluid velocity in the $\mathrm{i}^{\text {th }}$ direction

$\mathrm{D}_{\mathrm{ij}} \quad$ Effective diffusion coefficient for the species

$\mathrm{S}_{\mathrm{k}} \quad$ Source of species $k$

${ }_{k} \quad$ Net decay of species $k$

$\mathrm{i}, \mathrm{j} \quad$ Direction index

To obtain the tritium diffusion flux released from concrete waste blocks in the slit trenches, fractional fluxes for concrete blocks of a given size distribution were calculated. Individual flux of a given block size was calculated by flow and transport simulations of this single block placed in the trench. A composite fractional flux was generated from these 
individual fluxes and the overall block size distribution. The composite calculation also included tritium radiological decay. The composite flux is assumed to adequately represent the total actual tritium release.

\subsection{ASSUMPTIONS}

The following major assumptions were made in the PORFLOWTM simulations:

- The Trench Disposal Unit was assumed to be adequately represented in a twodimensional model as in the performance assessment for the E-area Low-Level Waste Facility (WSRC-RP-94-218, Revision 1).

- Water infiltration at the top of the domain was $40 \mathrm{~cm} / \mathrm{yr}$.

- Longitudinal and transverse dispersivities were zero.

- Negligible tritium sorption occurred on the solids (concrete or sediment; i.e., $\mathrm{K}_{\mathrm{d}}=0$ $\mathrm{mL} / \mathrm{g}$ ).

- Laboratory moisture characteristic curves (i.e., capillary pressure and relative permeability fraction vs. water saturation fraction) used for the PA report were applicable to the steady-state flow simulations carried out in the work.

- Tritium diffusion flux obtained by simulations of a single concrete waste block at different sizes was additive, i.e., effects of cluster of waste blocks were not considered.

- Tritium contamination was uniformly distributed through the concrete block (Hochel and Clark 2002).

\subsection{CONCEPTUAL MODEL}

The physical conceptual model to describe the materials, layout, and dimensions of the slit trenches is illustrated in Figure 1. Tritium diffusion was modeled for the first $25 \mathrm{yr}$, during which time waste was assumed to be placed in the trenches and covered with backfill soil, no horizontal barrier (cap) was in place. Water infiltration at the top of the modeling domain was set to $40 \mathrm{~cm} / \mathrm{yr}$. 


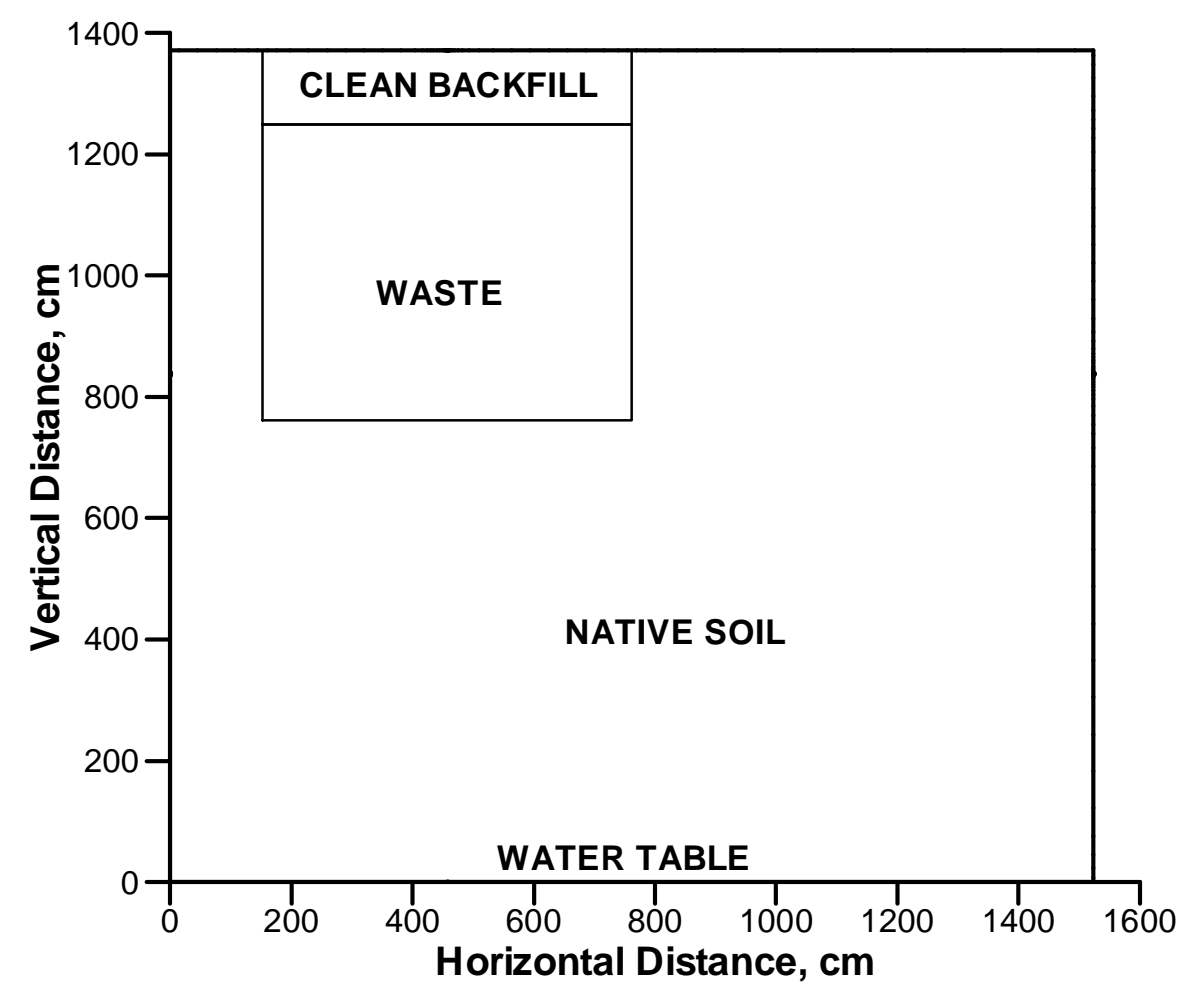

Figure 1. Conceptual Model.

The modeling grid used for the simulations is displayed in Figure 2. In order to provide numerical stability the meshes had a gradual transition from wider grids to narrower grids near the boundaries and where there are changes in material properties. The dark bands represent the narrow grids where the hypothetical concrete waste existed. A blowup of Figure 2, containing a $2 \mathrm{~cm} \times 1 \mathrm{~cm}$ concrete block is presented in Figure 3. 


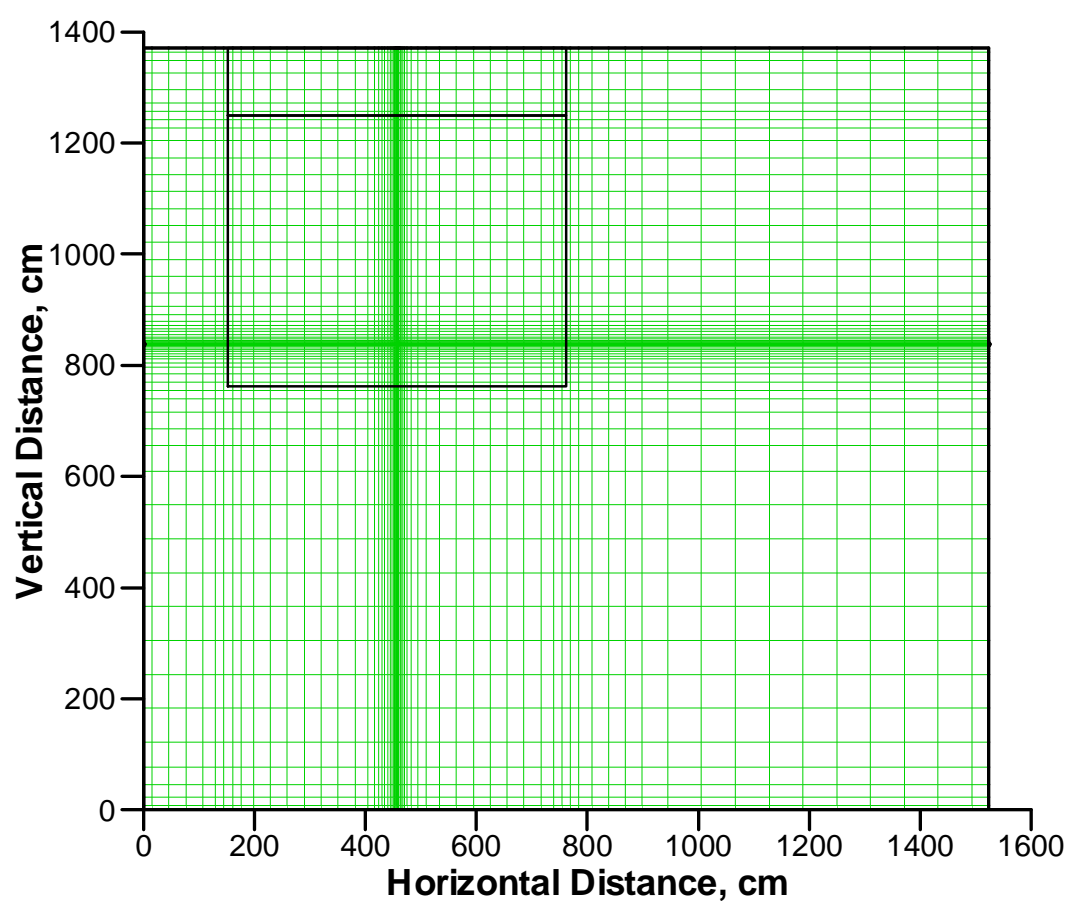

Figure 2. Modeling Grid.

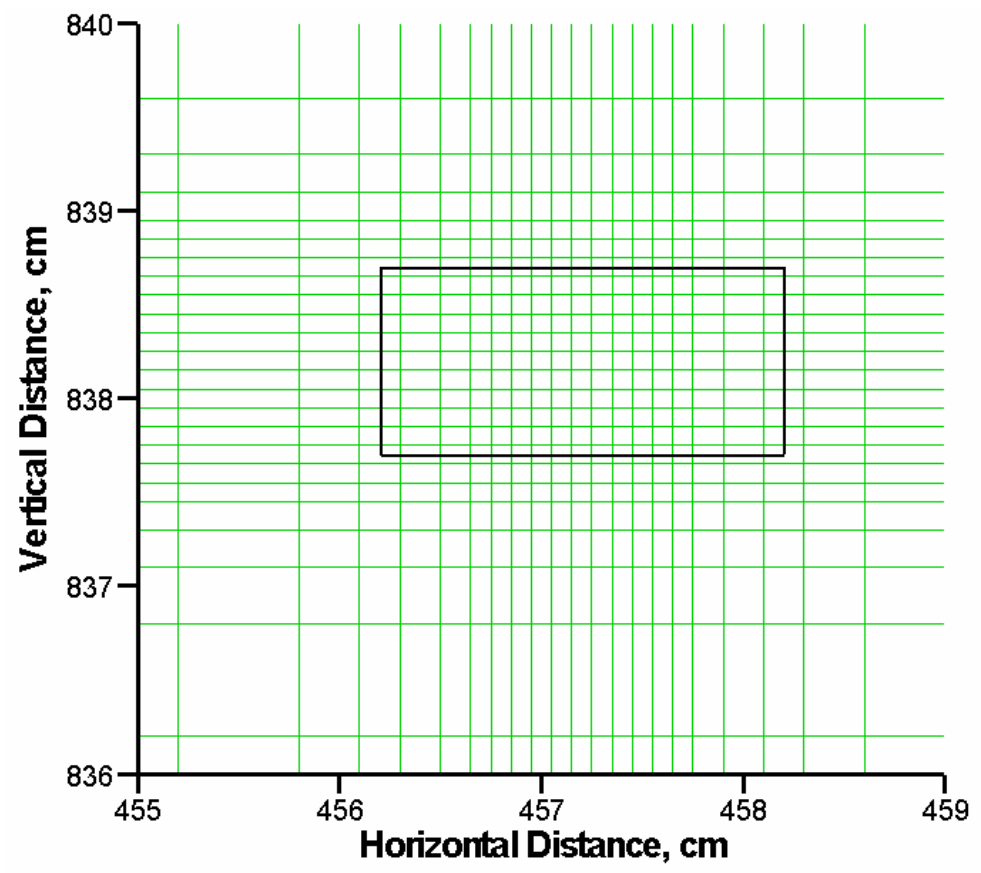

Figure 3. $2 \mathrm{~cm} \mathrm{x} 1 \mathrm{~cm}$ Concrete Waste Block. 
The material properties used in the PORFLOW ${ }^{\mathrm{TM}}$ simulations are listed in Table 1. The data were provided by L. B. Collard (private communications)

Table 1. Model Input Values for Materials.

\begin{tabular}{lcccc} 
& Waste & Clean Backfill & Native Soil & Concrete \\
\hline Density $\left(\mathrm{g} / \mathrm{cm}^{3}\right)$ & 2.65 & 2.65 & 2.65 & 2.65 \\
Porosity & 0.38 & 0.51 & 0.42 & 0.2 \\
Diffusion Coefficient $\left(\mathrm{cm}^{2} / \mathrm{yr}\right)$ & 158 & 158 & 158 & 1.58 \\
\hline
\end{tabular}

In each simulation, a concrete waste block of a given size was first placed into the fine mesh region of the waste trench. A steady-state flow field was generated by running the flow simulation for 3000 years. For illustration, Figure 4 shows the flow field obtained in the simulation of a $2 \mathrm{~cm} \times 1 \mathrm{~cm}$ concrete block. The steady-state flow field was then used in the subsequent transport simulation. In each transport simulation, an initial inventory of $1 \mathrm{Ci}$ of tritium was assumed for each waste block. Once the annual fractional tritium release rate was calculated for each of the five waste block sizes, a composite flux was calculated for a hypothetical concrete rubble pile buried in the E-Area slit trench. This was done by summing the annual fluxes estimated for each block size after they had been weighted to reflect the block size distributions observed in an actual concrete rubble pile (Section 4.0).

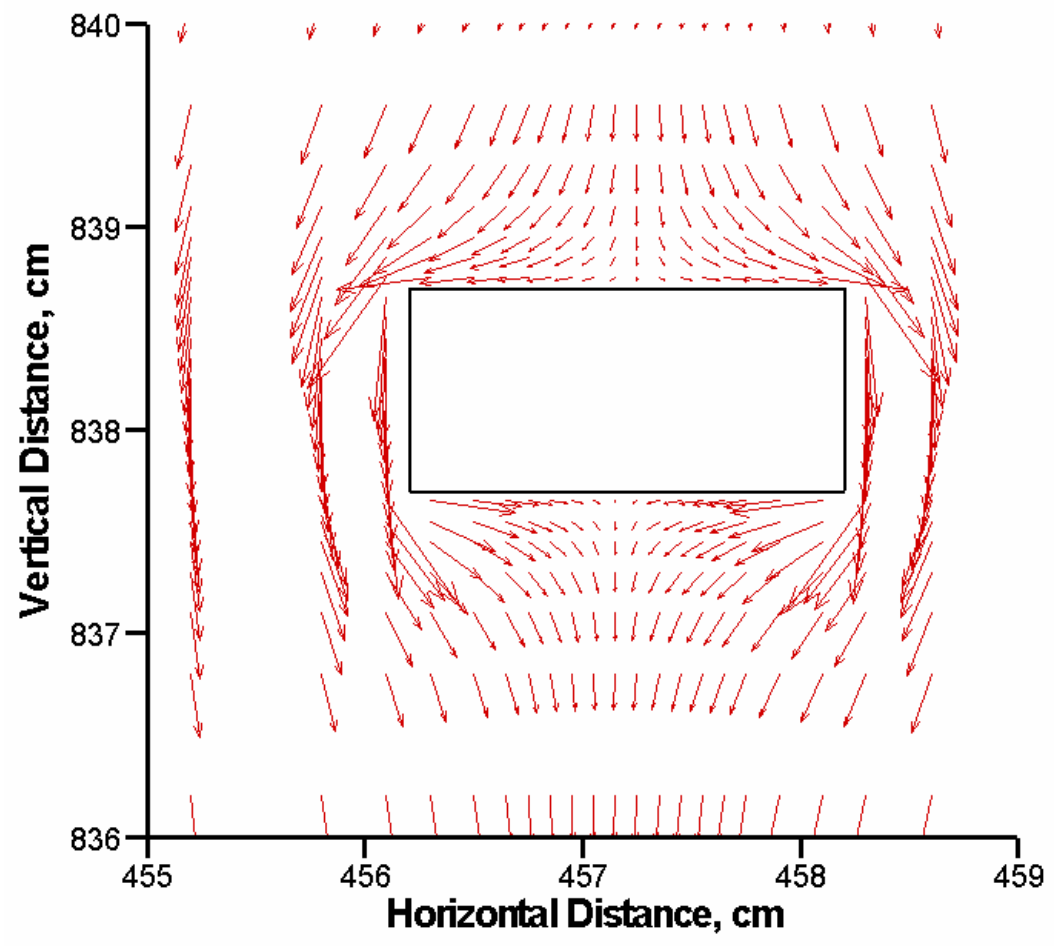

Figure 4. Flow Simulation of $2 \mathrm{~cm} x 1 \mathrm{~cm}$ Concrete Waste Block. 


\subsection{ESTIMATION OF CONCRETE RUBBLE SIZE DISTRIBUTION}

The particle size distribution (PSD) was measured for an existing concrete rubble pile. This concrete rubble was generated during the demolition of a large concrete saddle and did not contain tritium. The rubble along with soil from the original demolition site was transported to the C and D Landfill prior to the study. The field measurements of the PSD were carried out within one week of the generation of the rubble. In general the concrete rubble pile was of heterogeneous composition with regard to the size distribution of the concrete pieces. The majority of the volume of the pile consisted of large sections of concrete (greater than one foot at the narrowest diameter) with several piles of smaller concrete pieces (minimum diameter of less than one foot) mixed together with soil found among the larger concrete blocks (Figure 5).

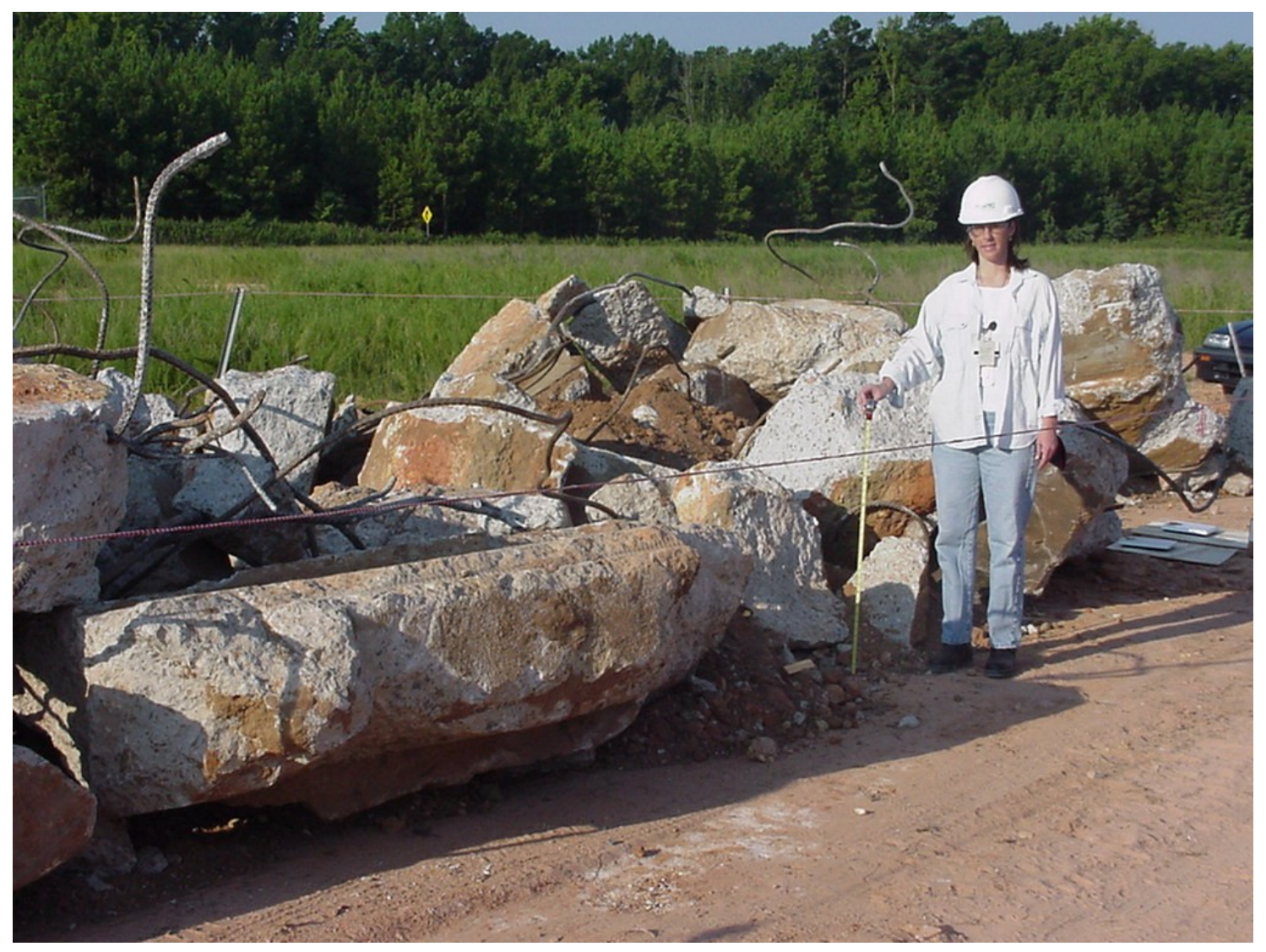

Figure 5. Concrete Rubble Pile at the C and D Landfill.

A $10 \mathrm{ft}$ X $20 \mathrm{ft}$ section of the concrete rubble pile was selected as a representative study area (shown in the foreground of Figure 5). A smaller $3 \mathrm{ft} \mathrm{X} 3 \mathrm{ft}$ subsection of the larger study area was selected as representative of the smaller fraction of rubble mixed with soil (shown in Figure 6). It was estimated that the $3 \times 3 \mathrm{ft}$ subsection represented approximately one 
fifth of the total amount of smaller rubble and soil within the larger $10 \mathrm{ft} X 20 \mathrm{ft}$ study area. Within the $10 \mathrm{ft}$ X $20 \mathrm{ft}$ study area all of the individual concrete blocks too large to lift were measured in three dimensions in order to determine the approximate volume of each. These larger blocks of concrete were categorized based on their minimum diameter according to modeled fractions. In the $3 \mathrm{ft} X 3 \mathrm{ft}$ subsection large pieces of soil and river rocks clearly not a part of the concrete composition were removed by hand and discarded. The majority of the concrete pieces greater than $19 \mathrm{~mm}$ were separated by hand, measured, and categorized by their minimum diameter. The remaining dirt and small concrete pieces were weighed and sieved through a $19 \mathrm{~mm}$ (3/4 inch US Standard) sieve. The concrete and soil passing through the $19 \mathrm{~mm}$ sieve was divided and approximately $40 \%$ of the material was further characterized by passing through a $9.50 \mathrm{~mm}$ and then a $4.75 \mathrm{~mm}$ sieve. The soil and concrete could readily be separated by hand in the $>19 \mathrm{~mm}, 19 \mathrm{~mm}-9.50 \mathrm{~mm}$, and $9.50-4.75 \mathrm{~mm}$ fractions. The concrete and soil passing through the $4.75 \mathrm{~mm}$ sieve could not be readily separated by hand.

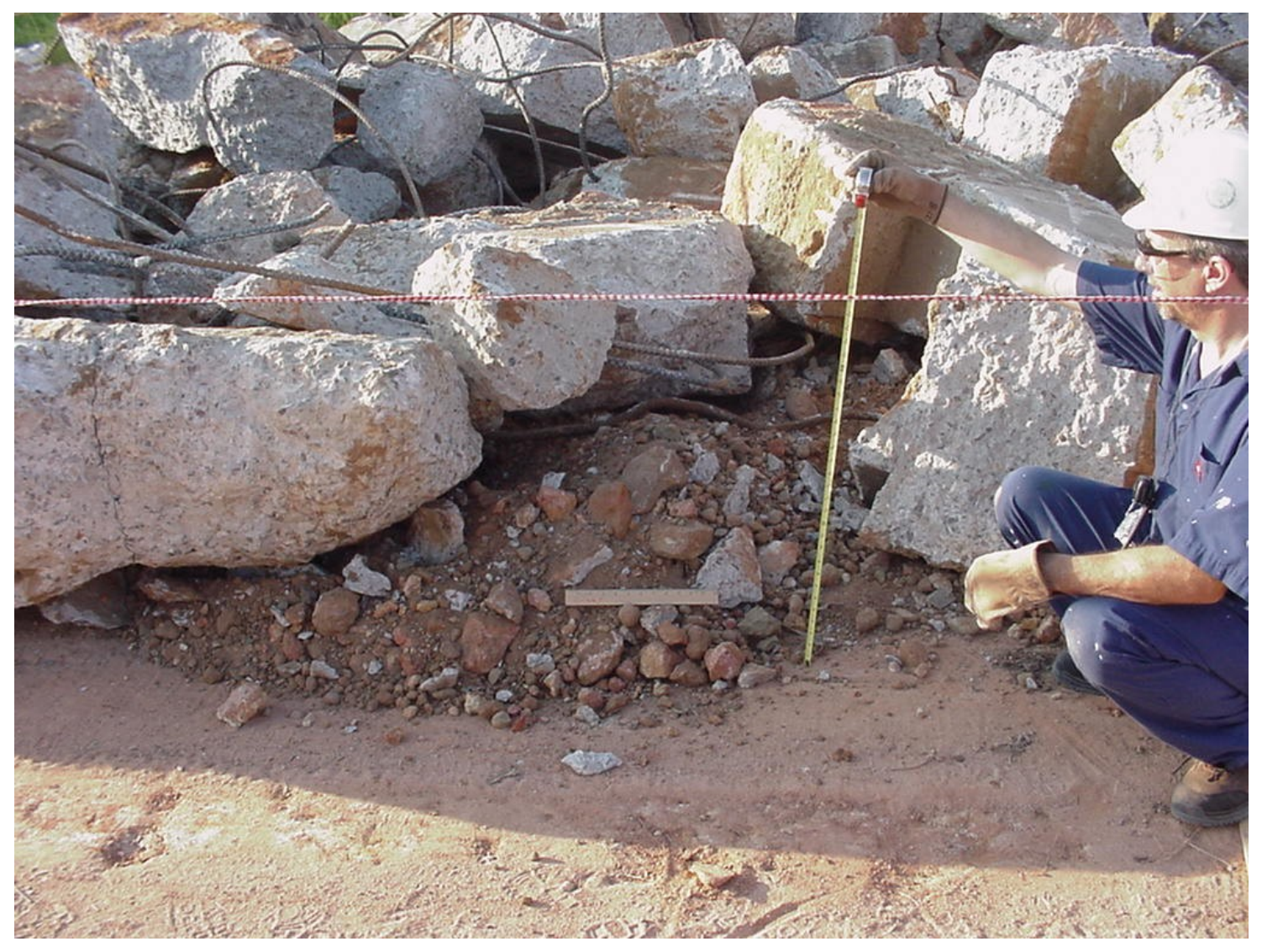

Figure 6. $3 \mathrm{ft}$ X $3 \mathrm{ft}$ Study Area with Smaller Concrete Rubble Mixed with Soil.

Two estimated particle size distributions were developed based on these studies. The first PSD (APPENDIX A: Estimation of Concrete Rubble Size Distribution) was based on the particle size distribution of the concrete rubble in the entire $10 \mathrm{ft} \mathrm{X} 20 \mathrm{ft}$ study area (using the $3 \mathrm{ft} X 3 \mathrm{ft}$ area to estimate the smaller rubble distributed over the entire area). This particle size distribution is considered to be the "Best-Estimate" block size distribution and considers both the large and smaller concrete blocks. The second PSD (APPENDIX A: Estimation of 
Concrete Rubble Size Distribution) was based only on the particle size distribution of concrete in the $3 \mathrm{ft} X 3 \mathrm{ft}$ study area. The smaller study area is considered a conservative estimate based only on the size distribution of the smaller concrete rubble generated during demolition.

The fractions 1-5 (and) were assigned based on fractions previously modeled. A density of $145 \mathrm{lb} / \mathrm{ft}^{3}$ for concrete (per Christine Langton) was assumed in order to calculate the percent by volume of each fraction. For the $10 \mathrm{ft} \mathrm{X} 20 \mathrm{ft}$ study area it was assumed 1) that the $3 \mathrm{ft} X$ $3 \mathrm{ft}$ subsection represented $20 \%$ of the small rubble and dirt within the $10 \mathrm{ft} \mathrm{X} 20 \mathrm{ft}$ area and 2) all material (both soil and concrete) passing through the $4.75 \mathrm{~mm}$ sieve was concrete (Fraction 1;Table 2). This second assumption was considered conservative because it was estimated that this mixture consisted of less than $5 \%$ concrete. For the smaller concrete rubble in the $3 \mathrm{ft} X 3 \mathrm{ft}$ study area it was assumed that $5 \%$ of all material (soil and concrete) passing through the $4.75 \mathrm{~mm}$ sieve was concrete (Fraction 1 ; Table 3 ).

Methods and additional information regarding these studies is provided in APPENDIX A: Estimation of Concrete Rubble Size Distribution.

Table 2. Best-Estimate Particle Size Distribution of Concrete in the $10 \mathrm{ft} X 20 \mathrm{ft}$ Study Area.

\begin{tabular}{|c|ccc|}
\hline Fraction & Length $(\mathrm{cm})$ & Width $(\mathrm{cm})$ & $\%$-vol \\
\hline 1 & 0.4 & 0.2 & 3.48 \\
2 & 1.2 & 0.6 & 0.04 \\
3 & 2 & 1 & 0.11 \\
4 & 16 & 8 & 1.95 \\
5 & 60 & 30 & 94.42 \\
& Total & & 100 \\
\hline
\end{tabular}

Table 3. Small Block Particle Size Distribution Within the $3 \mathrm{ft} X 3 \mathrm{ft}$ Study Area.

\begin{tabular}{|c|ccc|}
\hline Fraction & Length $(\mathrm{cm})$ & Width $(\mathrm{cm})$ & $\%$-vol \\
\hline 1 & 0.4 & 0.2 & 19.28 \\
2 & 1.2 & 0.6 & 4.02 \\
3 & 2 & 1 & 12.37 \\
4 & 16 & 8 & 64.33 \\
5 & 60 & 30 & 0.00 \\
& Total & & 100 \\
\hline
\end{tabular}




\subsection{RESULTS AND DISCUSSION}

The fractional annual ${ }^{3} \mathrm{H}$ fluxes from the five modeled block sizes are presented in Figure 7 through Figure 11. As the block size increased, the duration increased before the entire $1 \mathrm{Ci}$ inventory of ${ }^{3} \mathrm{H}$ had diffused out of the blocks and had traveled by dispersion and advection through the vadose zone into the underlying aquifer. For the three smallest block sizes $(0.4 \mathrm{~cm} \times 0.2 \mathrm{~cm}, 1.2 \mathrm{~cm} \times 0.6 \mathrm{~cm}$, and $2 \mathrm{~cm} \times 1 \mathrm{~cm})$, the entire $1 \mathrm{Ci}^{3} \mathrm{H}$ inventory reached the underlying aquifer within one year. The two larger blocks required several years for the ${ }^{3} \mathrm{H}$ to reach the underlying aquifer (Figure 10 and Figure 11).

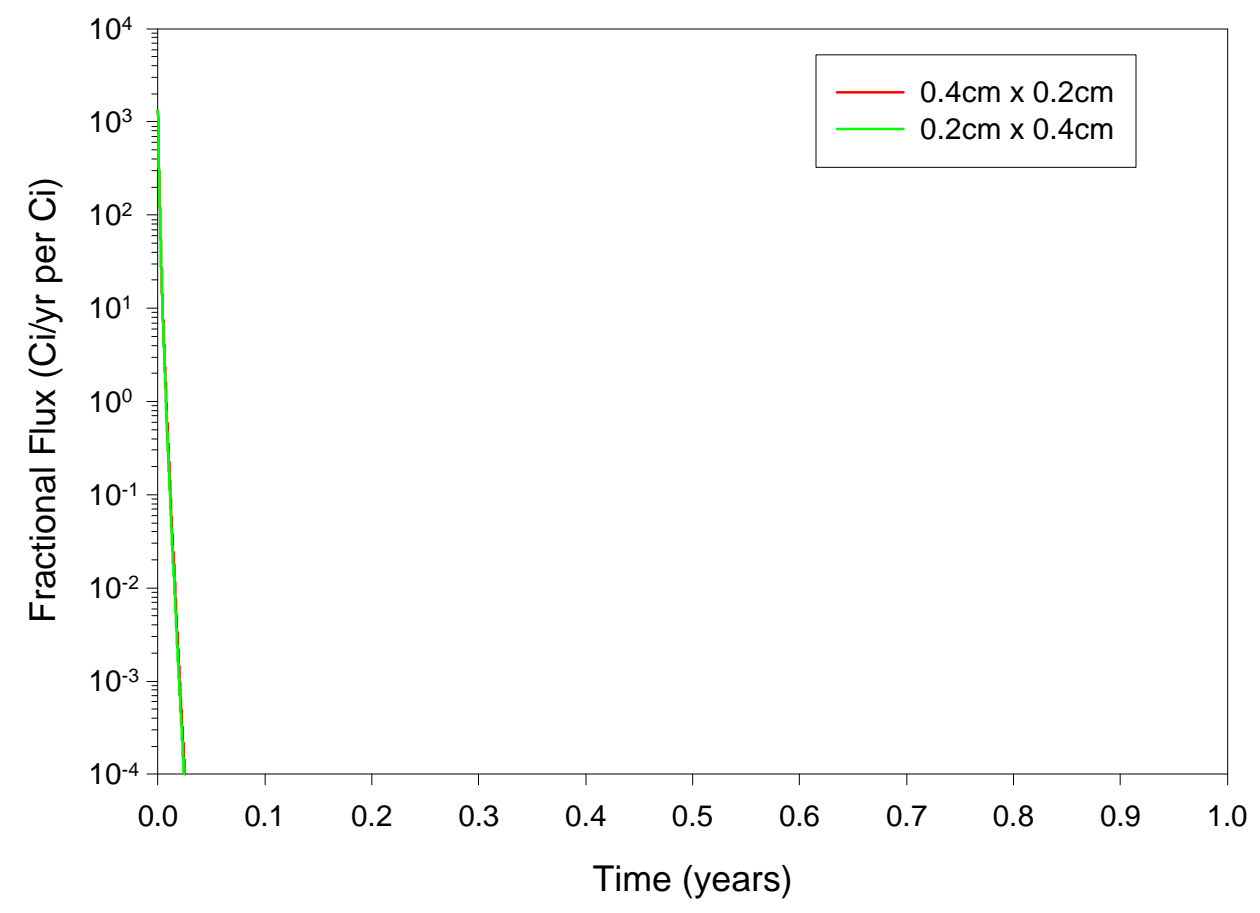

Figure 7. Fractional Flux of ${ }^{3} \mathrm{H}(0.4 \mathrm{~cm} \times 0.2 \mathrm{~cm}$ Concrete Waste Block; Initial Inventory: 1Ci; Concrete Molecular Diffusivity: $5 \mathrm{E}-8 \mathrm{~cm}^{2} / \mathrm{s}$ ). 
WSRC-TR-2004-00215, REV. 0

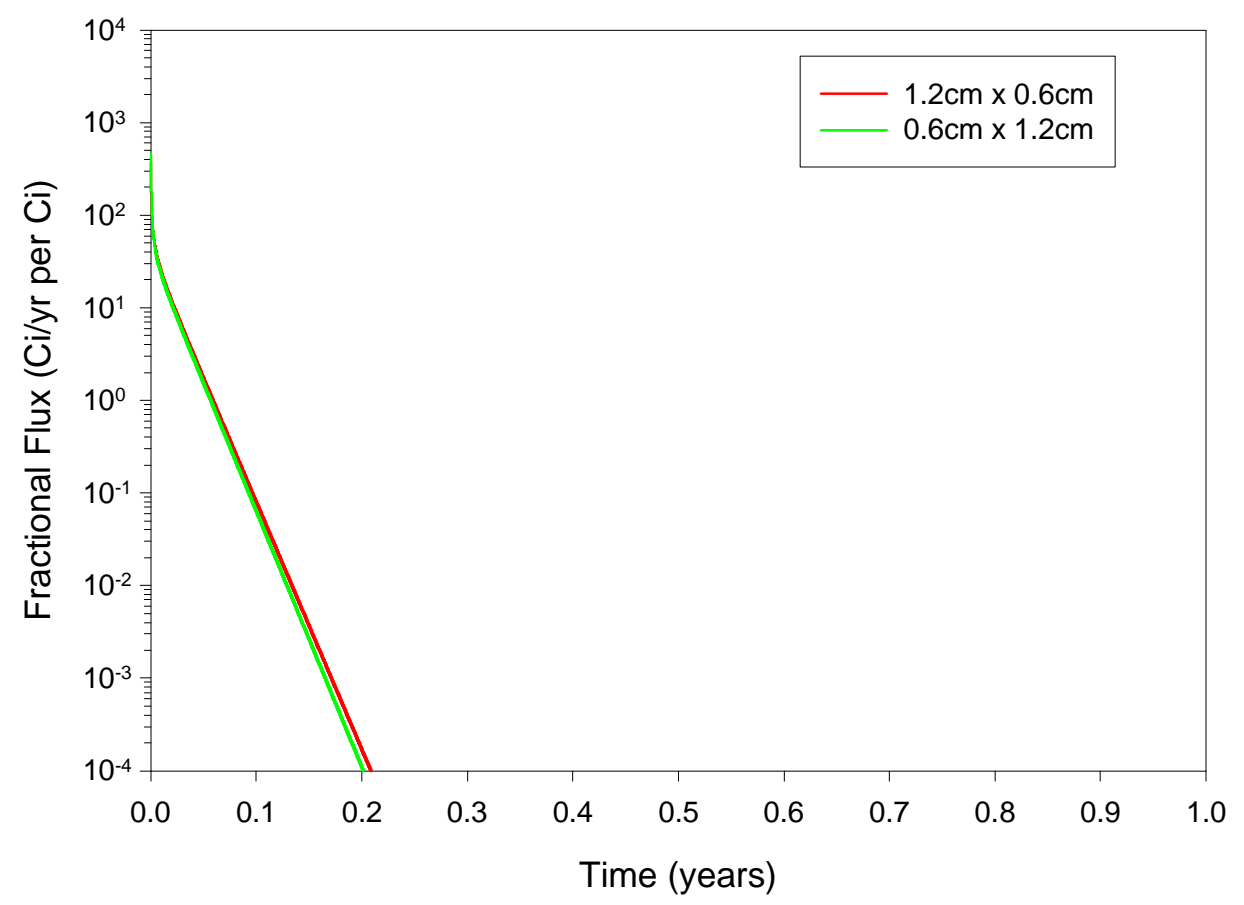

Figure 8. Fractional Flux of ${ }^{3} \mathrm{H}(1.2 \mathrm{~cm} \times 0.6 \mathrm{~cm}$ Concrete Waste Block; Initial Inventory: 1Ci; Concrete Molecular Diffusivity: $5 \mathrm{E}-8 \mathrm{~cm}^{2} / \mathrm{s}$ ).

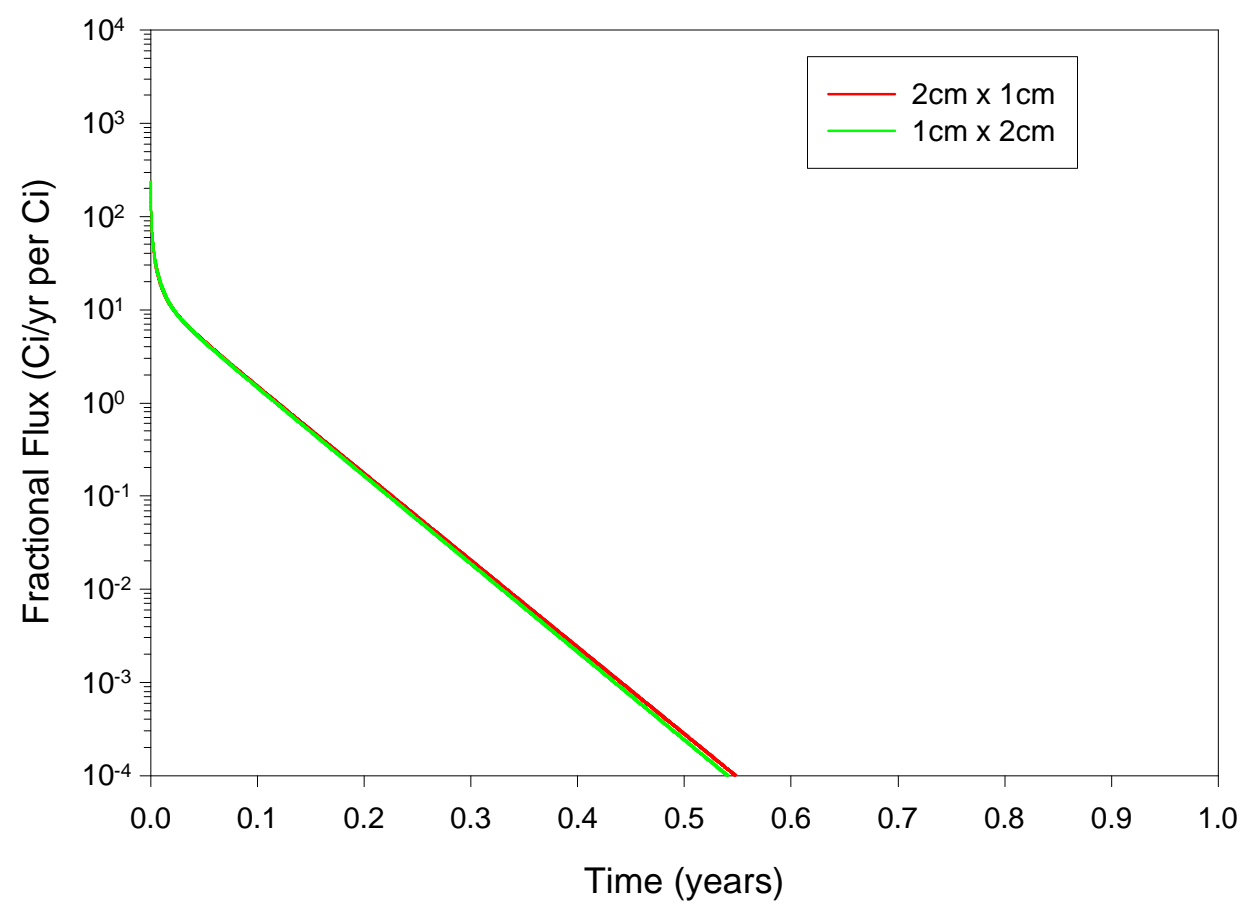

Figure 9. Fractional Flux of ${ }^{3} \mathrm{H}(2 \mathrm{~cm} \times 1 \mathrm{~cm}$ Concrete Waste Block; Initial Inventory: $1 \mathrm{Ci}$; Concrete Molecular Diffusivity: $5 \mathrm{E}-8 \mathrm{~cm}^{2} / \mathrm{s}$ ). 
WSRC-TR-2004-00215, REV. 0

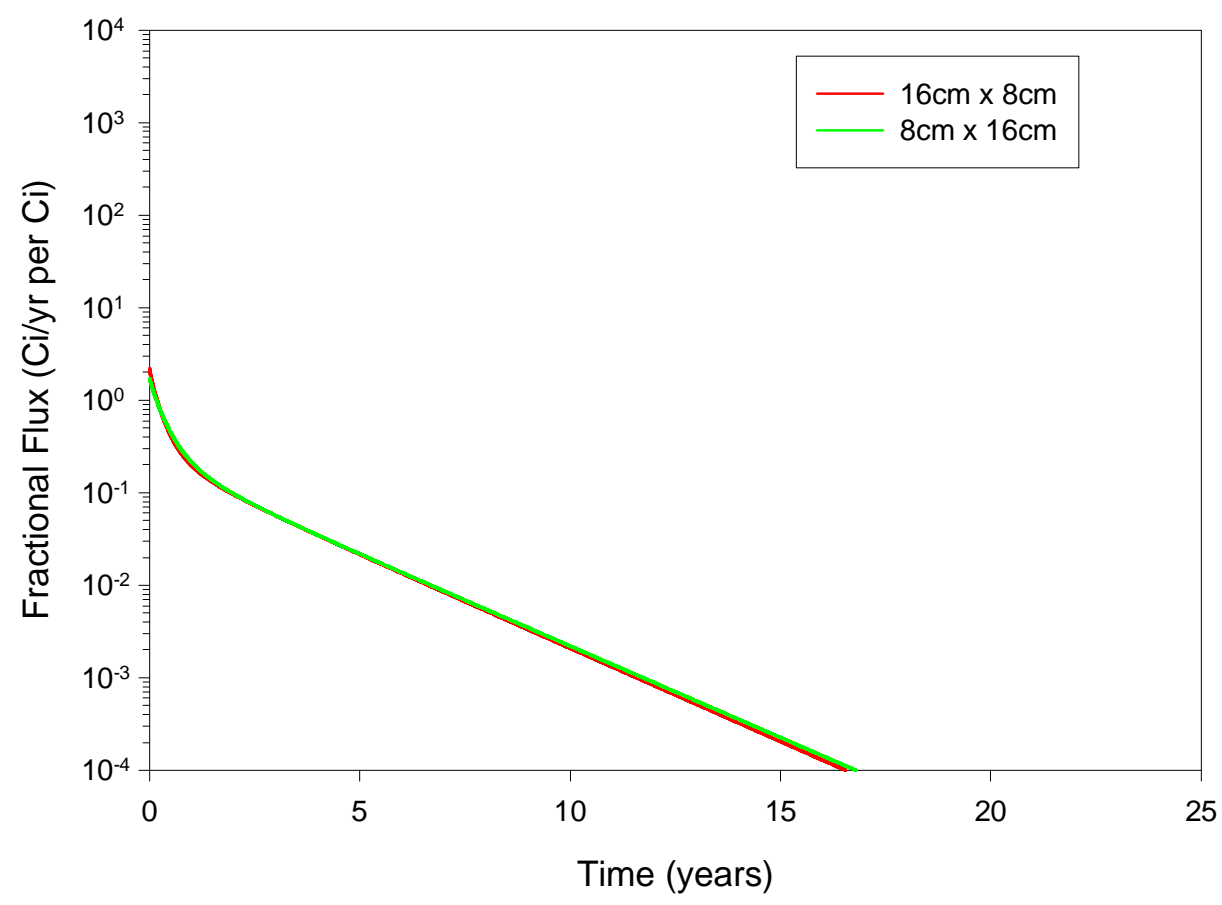

Figure 10. Fractional Flux for ${ }^{3} \mathrm{H}(16 \mathrm{~cm} \times 8 \mathrm{~cm}$ Concrete Waste Block; Initial Inventory: 1Ci; Concrete Molecular Diffusivity: $5 \mathrm{E}-8 \mathrm{~cm}^{2} / \mathrm{s}$ ).

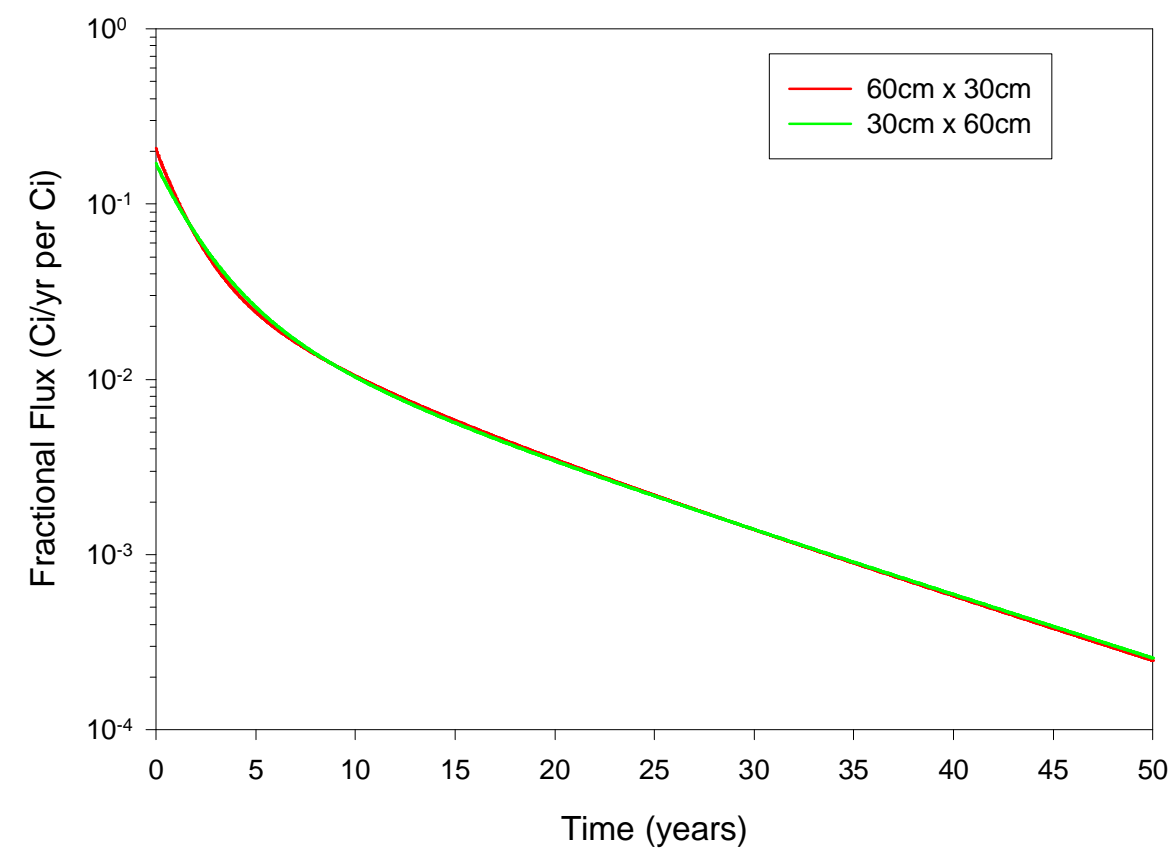

Figure 11. Fractional Flux of ${ }^{3} \mathrm{H}(60 \mathrm{~cm} \times 30 \mathrm{~cm}$ Concrete Waste Block; Initial Inventory: 1Ci; Concrete Molecular Diffusivity: $\left.5 \mathrm{E}-8 \mathrm{~cm}^{2} / \mathrm{s}\right)$. 
The composite fractional flux of ${ }^{3} \mathrm{H}$ for the best-estimate and the smaller (conservative) block size distributions are presented in Figure 12. The best-estimate distribution is based on field measurements (Section 4.0). The smaller block size distribution reflects an arbitrary conservative estimate in which the largest block size, i.e., the $60 \mathrm{~cm} \times 30 \mathrm{~cm}$ blocks, were excluded from the transport calculation. The results differ substantially, in that the bestestimate scenario containing the largest class of blocks produced a much slower annual flux.

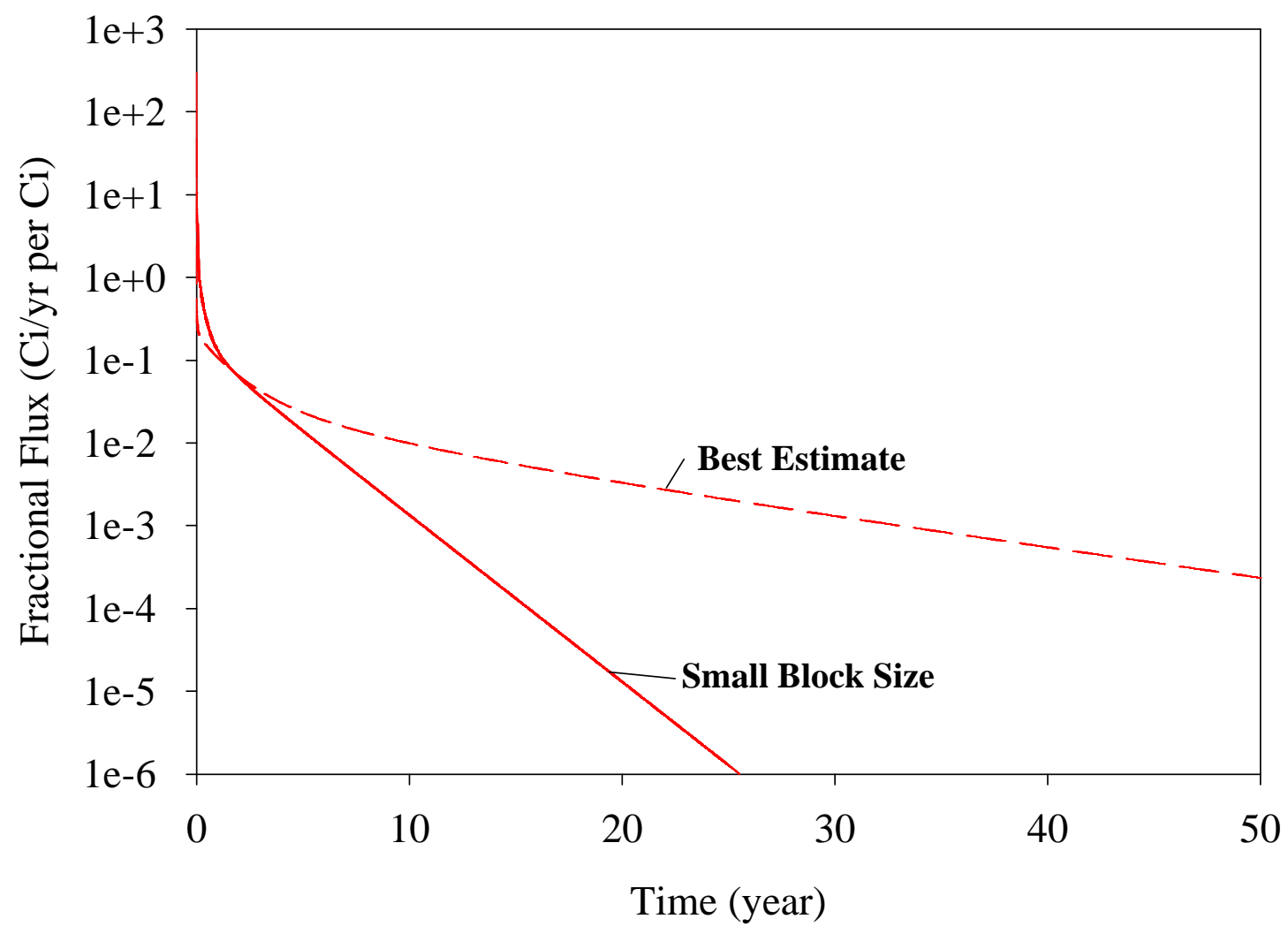

Figure 12. Composite Fractional Flux of ${ }^{3} \mathrm{H}$ for the Best-Estimate Block Size Distribution and the Small Block Size Distribution (Initial Inventory: 1Ci; Concrete Molecular Diffusivity: $\left.5 \mathrm{E}-8 \mathrm{~cm}^{2} / \mathrm{s}\right)$.

Figure 13 and Figure 14 were created from the same data used to create Figure 12, but were expressed in terms of cumulative radioactivity lost due to transport (diffusion and advection) and decay. For the best-estimate scenario (Figure 13), 90\% of the tritium either decayed or was transported from the concrete rubble after $20 \mathrm{yr}$. Of this $90 \%$ tritium loss, about $50 \%$ was due to transport, whereas the remaining $40 \%$ was due to decay. The loss due to transport was more important during the initial $10 \mathrm{yr}$; afterwards, the two processes were equally important for controlling tritium concentrations. In the scenario consisting of a small block size distribution (Figure 14), 90\% of the tritium was loss after only $2.2 \mathrm{yr}$, and not surprisingly, transport was the most important process controlling tritium concentrations in the system. 


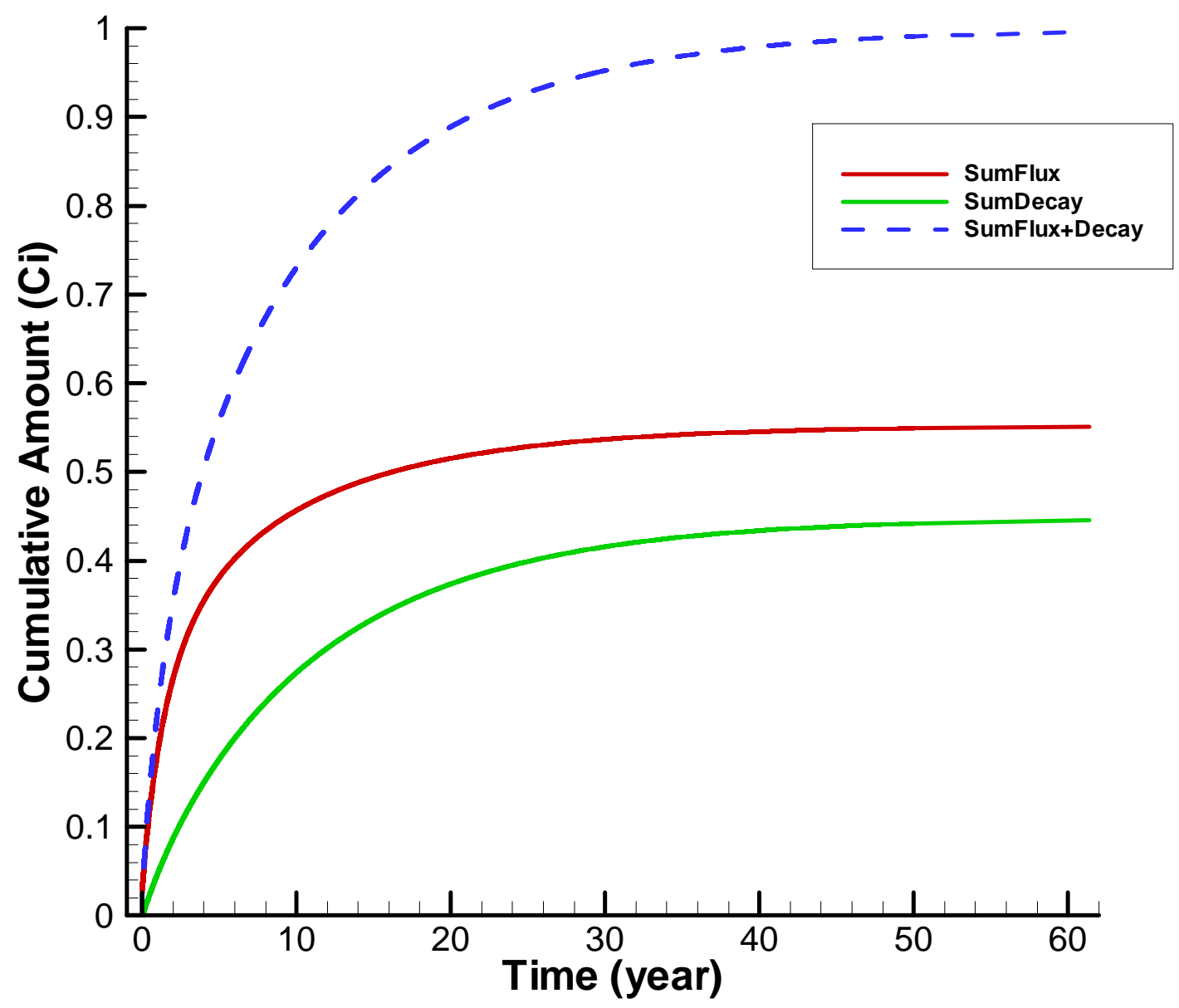

Figure 13. Cumulative Loss of ${ }^{3} \mathrm{H}$ from Concrete Blocks with the Best-Estimate Size Distribution (Initial Inventory: 1Ci; Concrete Molecular Diffusivity: $5 \mathrm{E}-8 \mathrm{~cm} / \mathrm{s}$; SumFlux Lost Due to Transport Only; SumDecay - Lost Due to Decay Only; SumFlux+Decay - Lost Due to Decay + Transport). 


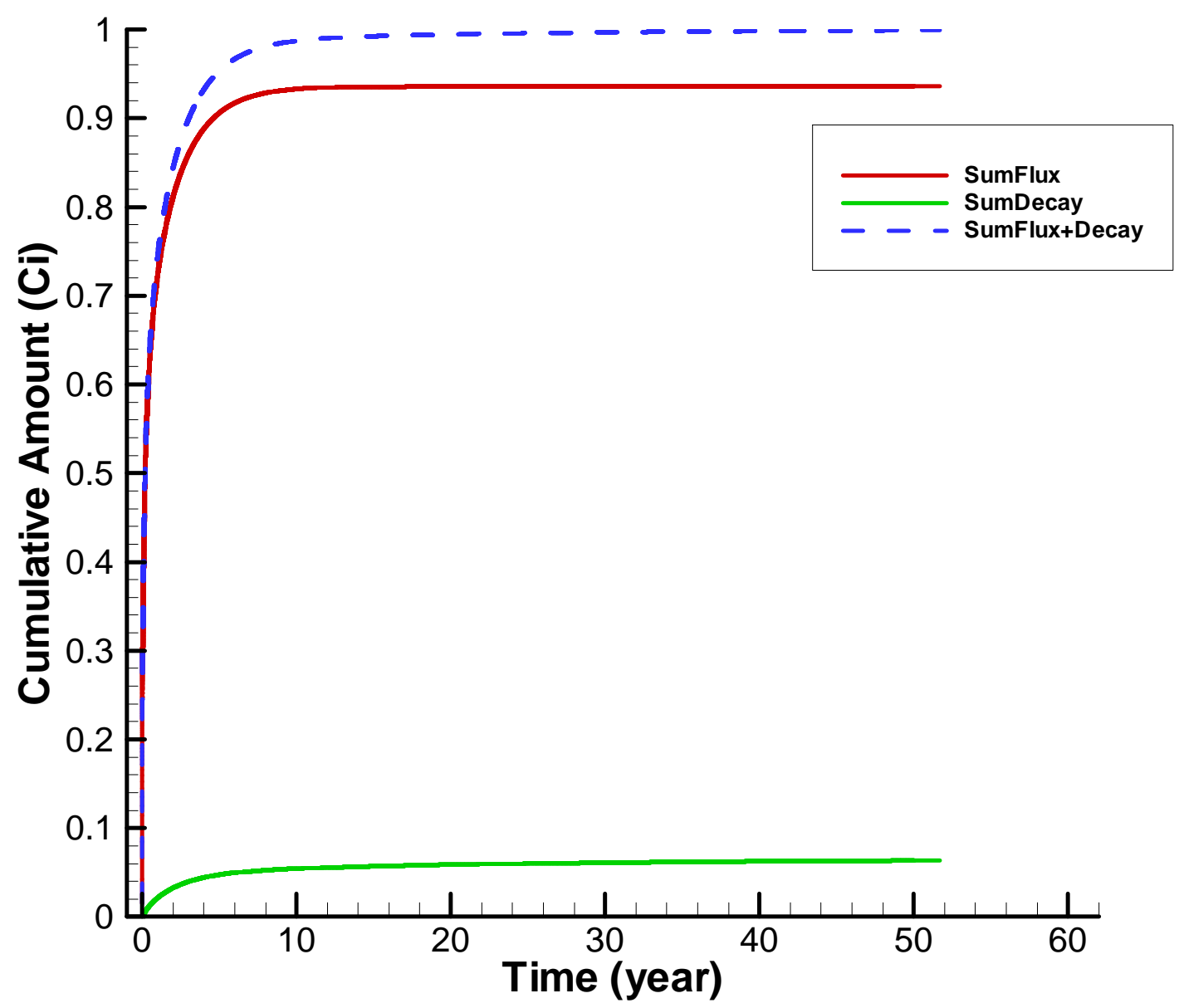

Figure 14. Cumulative Loss of ${ }^{3} \mathrm{H}$ from Concrete Blocks with a Small Block Size Distribution (Initial Inventory: 1Ci; Concrete Molecular Diffusivity: $5 \mathrm{E}-8 \mathrm{~cm}^{2} / \mathrm{s}$; SumFlux Lost Due to Transport Only; SumDecay - Lost Due to Decay Only; SumFlux+Decay - Lost Due to Decay + Transport). 


\subsection{CONCLUSIONS}

Simulations showed that for the best-estimate of concrete block size distribution that $\sim 90 \%$ of the tritium either decayed or was transported from the concrete rubble within 20 years. Of this $90 \%$ tritium loss, about 50\% was due to transport, whereas the remaining $40 \%$ was due to decay. Loss due to transport was more important during the initial 10 years; afterwards, the two processes were equally important for controlling tritium concentrations.

This report provides a first approximation quantifying tritium diffusion from concrete particles into groundwater. Additional work needs to be directed at quantifying the block size distribution of tritium-containing concrete rubble, the influence of inter-block interactions on diffusion processes, and uneven distribution of tritium within concrete rubble blocks.

\subsection{REFERENCES}

Hochel, R. C. , and E. A. Clark. 2002. Corroborative Studies of Tritium Characterization and Depth Profiles in Concrete. Radioactive Waste Management and Environ. Res. 22:394419.

McDowell-Boyer et al. 2000. Radiological Performance Assessment for the E-Area LowLevel Waste Facility. WSRC-RP-94-218, Rev. 1, WSRC, Aiken, SC. 
WSRC-TR-2004-00215, REV. 0

\subsection{APPENDIX A: ESTIMATION OF CONCRETE RUBBLE SIZE DISTRIBUTION}




\section{One Time Work Instruction for Measuring the Particle Size Distribution of Concrete Rubble Associated with SRS Demolition Activities}

Purpose: To measure the particle size distribution of concrete rubble from the demolition of a concrete slab.

\section{Required Materials:}

Camera

Sieves: $19 \mathrm{~mm}$ (3/4 inch), $12.5 \mathrm{~mm}$ (1/2 inch), $4 \mathrm{~mm}$

Commercial bathroom scales (2)

Calibration weights

Measuring tape (metal)

Drop cloth

Several Large buckets or containers

Laboratory notebook

\section{Safety equipment:}

SRSOC Radio

Drinking water

Safety glasses with side shields

Gloves

Hard hat

Steel-toed boots

Water for wet sieving

\section{Procedure:}

\section{Safety Procedures: See attached JHA}

Prior to departing for the study site:

1. Review conduct of R \& D, JHA, One time work instruction

2. Collect all required Materials and Safety equipment.

3. In the laboratory check the accuracy of the commercial scale verses calibrated weights.

4. In the laboratory weigh an item to be taken into the field to validate accuracy of scale in the field. Record weight in notebook.

5. Sign out truck

At the study site:

1. Photograph study site extensively. Particularly small fraction study area to show size relative all concrete deposited

2. Choose study area approximately $1 / 2$ of a skid pan.

3. Measure the dimensions of all sections of concrete $>2 \mathrm{ft}$ maximum diameter or $40 \mathrm{lbs}$. Record in lab notebook. 
4. Set up scale at a level location in the field and test with known weight. Record measurements in notebook.

5. Weigh drop cloth and bucket or pan. Record weight of each.

6. Select an area within the area of step 2 for analysis of the smaller fraction $(<2 \mathrm{ft}$ max diameter or $40 \mathrm{lbs}$ ).

7. Group all concrete chunks $>1 \mathrm{ft}$ minimum diameter but $<2 \mathrm{ft}$ max diameter.

8. Weigh individual chunk and record weight and smallest width in notebook.

9. Group all concrete chunks $<1 \mathrm{ft}$ minimum diameter but $>6$ inches minimum repeat step 8.

10. Group all concrete chunks $<6$ inches minimum diameter but $>3$ inches minimum diameter repeat step 8

11. Group all concrete chunks $<3$ inches minimum diameter but $>1$ inches minimum diameter repeat step 8.

12. Divide the remaining smaller fractions into fractions weighing $<40 \mathrm{lbs}$.

13. Place up to $40 \mathrm{lbs}$ on drop cloth.

14. Place drop cloth in a plastic bucket or place directly on scale.

15. Record weight.

16. Wet Sieve remaining concrete crumb through $19 \mathrm{~mm} ; 3 / 4$ inch US Standard (this is for the $2 \times 1 \mathrm{~cm}$ particles). Record weight of $>19 \mathrm{~mm}$ fraction after drying in air.

17. Wet Sieve remaining through $12.5 \mathrm{~mm} ; 1 / 2$ inch US Standard (this is for the $1.2 \times 0.6$ $\mathrm{cm}$ particles). Record weight of $>12.5 \mathrm{~mm}$ fraction after allowing to dry in air.

18. Wet Sieve remaining through $4 \mathrm{~mm}$; No. 5 US Standard (this is for the $0.4 \times 0.2 \mathrm{~cm}$ particles). Record weight of $>4 \mathrm{~mm}$ fraction after allowing to dry in air. 


\section{Job Hazard Analysis Form}

Job Title: Measuring Particle Size Distribution of Concrete Rubble Associated with SRS Demolition Activities

Job Location: C and D Landfill

JHA Preparation: K.R. Powell, W. Stevens

Participants in work: Carl Black and Sammie McDuffie

\begin{tabular}{|c|c|c|}
\hline KEY JOB STEPS & JOB HAZARDS & SAFE PRACTICES AND EQUIPMENT \\
\hline 1. Work out-of-doors & Heat stress & $\begin{array}{c}\text { Work planned only in morning, } \\
\text { Radio for communication with SRSOC for } \\
\text { heat stress updates } \\
\text { Will call SRSOC at 5-1911 to report remote } \\
\text { worker location before and after job } \\
\text { Will carry water into field, } \\
\text { Will follow SRS heat Stress Management } \\
\text { Guidelines }\end{array}$ \\
\hline 2.Work in landfill & $\begin{array}{l}\text { Working in landfill near } \\
\text { large heavy equipment }\end{array}$ & Barricade rope around work area \\
\hline $\begin{array}{l}\text { 3. Sieving concrete and dirt } \\
\text { mixed therein }\end{array}$ & $\begin{array}{c}\text { Airborne dusts } \\
\text { (particularly silica) }\end{array}$ & Wet sieving only (per Industrial Hygiene) \\
\hline 4. Weighing concrete pieces & $\begin{array}{l}\text { 1. Potential injury due to } \\
\text { working around unstable } \\
\text { large pieces of concrete } \\
\text { 2. Rebar protruding from } \\
\text { concrete } \\
\text { 3. Potential lifting injury } \\
\text { from moving blocks of } \\
\text { concrete } \\
\text { 4. Injury caused by concrete } \\
\text { dropped or falling pieces }\end{array}$ & $\begin{array}{l}\text { 1. Work only in areas away from } \\
\text { large blocks of concrete } \\
\text { 1. Hard hats will be worn } \\
\text { 1. Steel-toed shoes will be worn } \\
\text { 1. Use shovel to test stability and } \\
\text { remove small fraction to safe area } \\
\text { for analysis } \\
\text { 2. Hard hats will be worn } \\
\text { 2. Use shovel to remove small } \\
\text { fraction to safe area for analysis } \\
\text { 2 Safety glasses } \\
\text { 3. Move only blocks } \\
<2 \text { ft maximum diameter or } 40 \text { lbs } \\
\text { 3. Use proper lifting techniques } \\
\text { 4. Steel-toed shoes will be worn } \\
\text { 4. Gloves will be worn }\end{array}$ \\
\hline \multicolumn{3}{|l|}{ "JHA Acceptance Signature/Date } \\
\hline
\end{tabular}




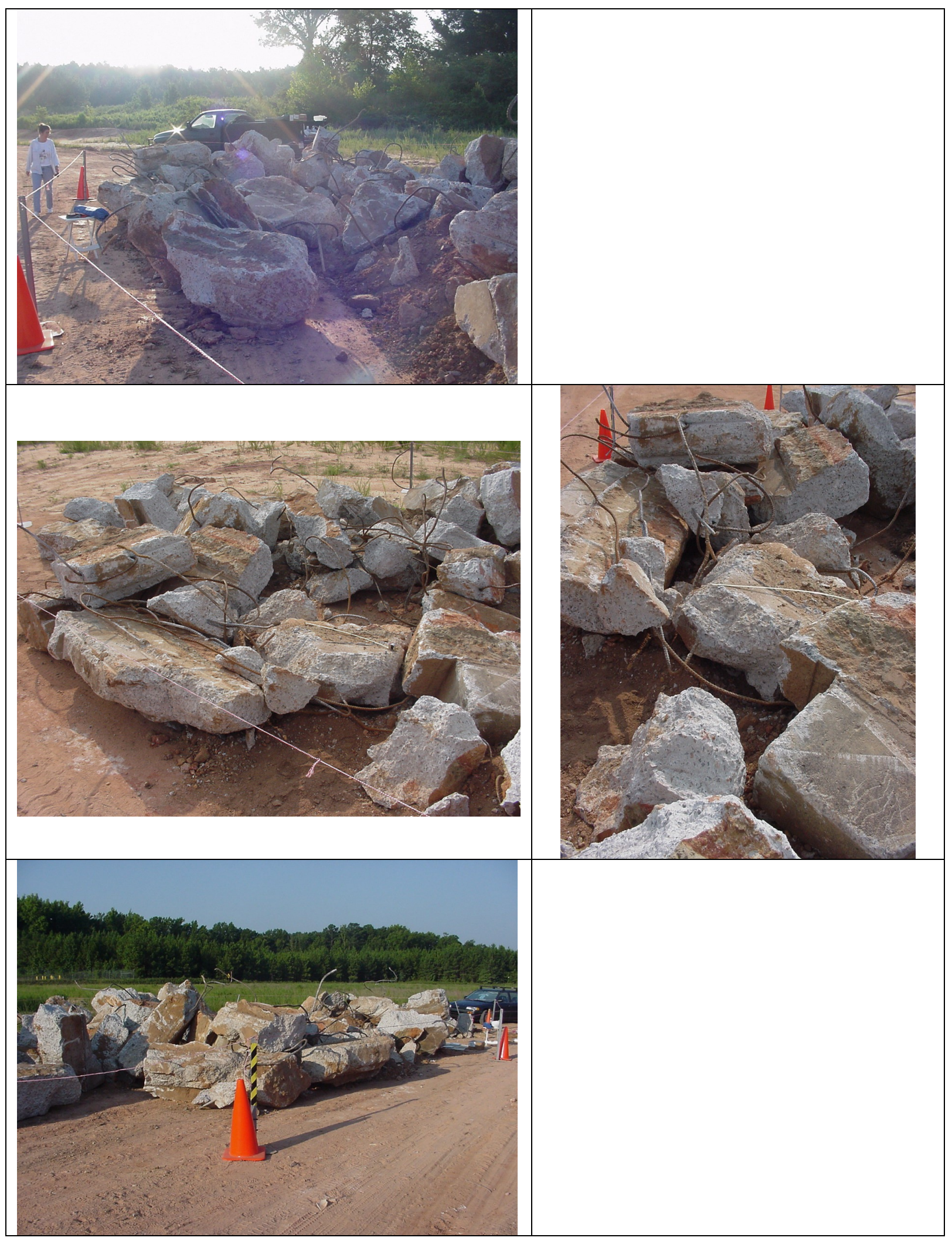

Figure A1. Views of the concrete rubble pile including the $10 \mathrm{ft} X 20 \mathrm{ft}$ study area 
WSRC-TR-2004-00215, REV. 0

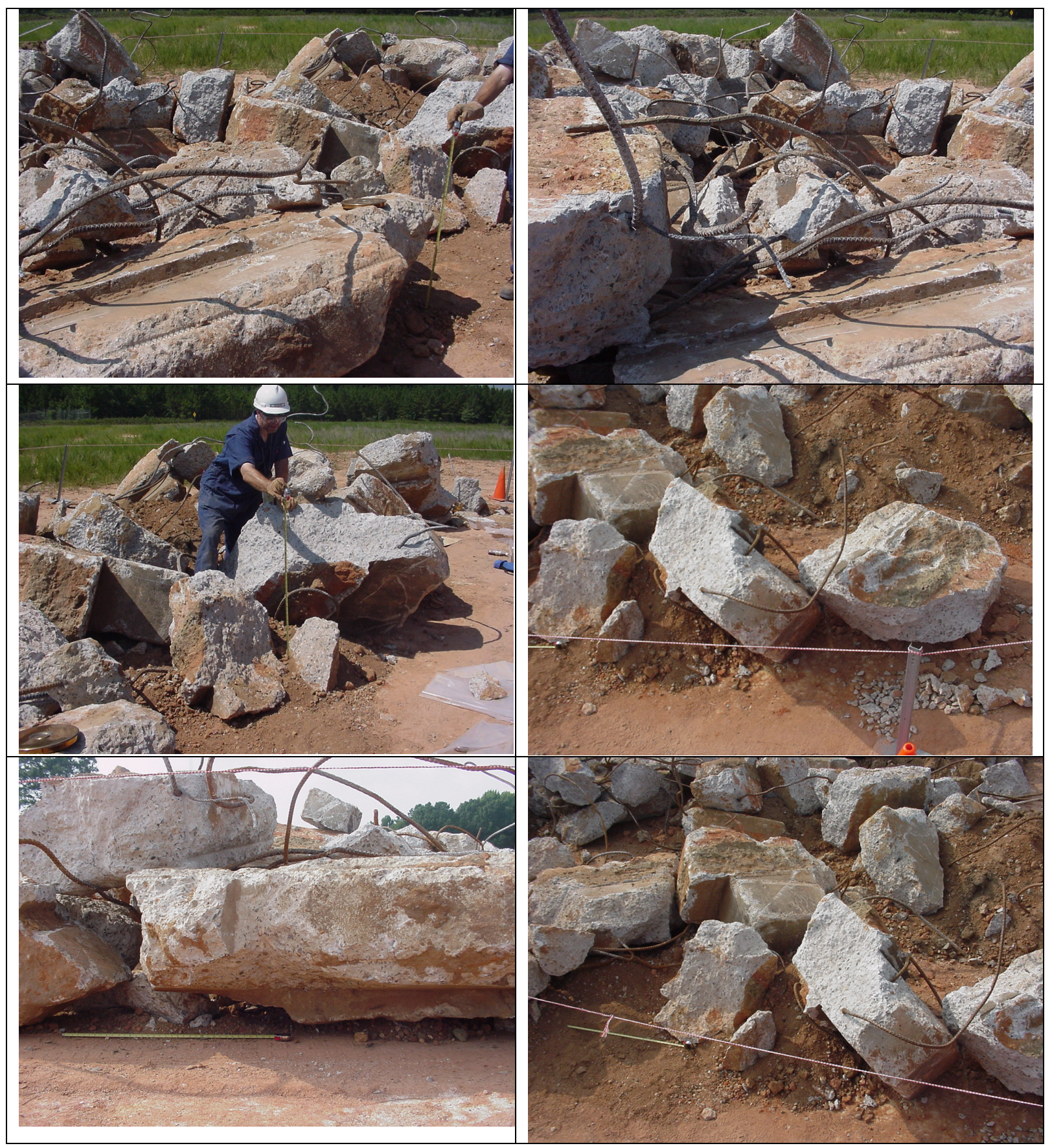

Figure A2. Views of the $10 \mathrm{ft} X 20 \mathrm{ft}$ study area 
WSRC-TR-2004-00215, REV. 0

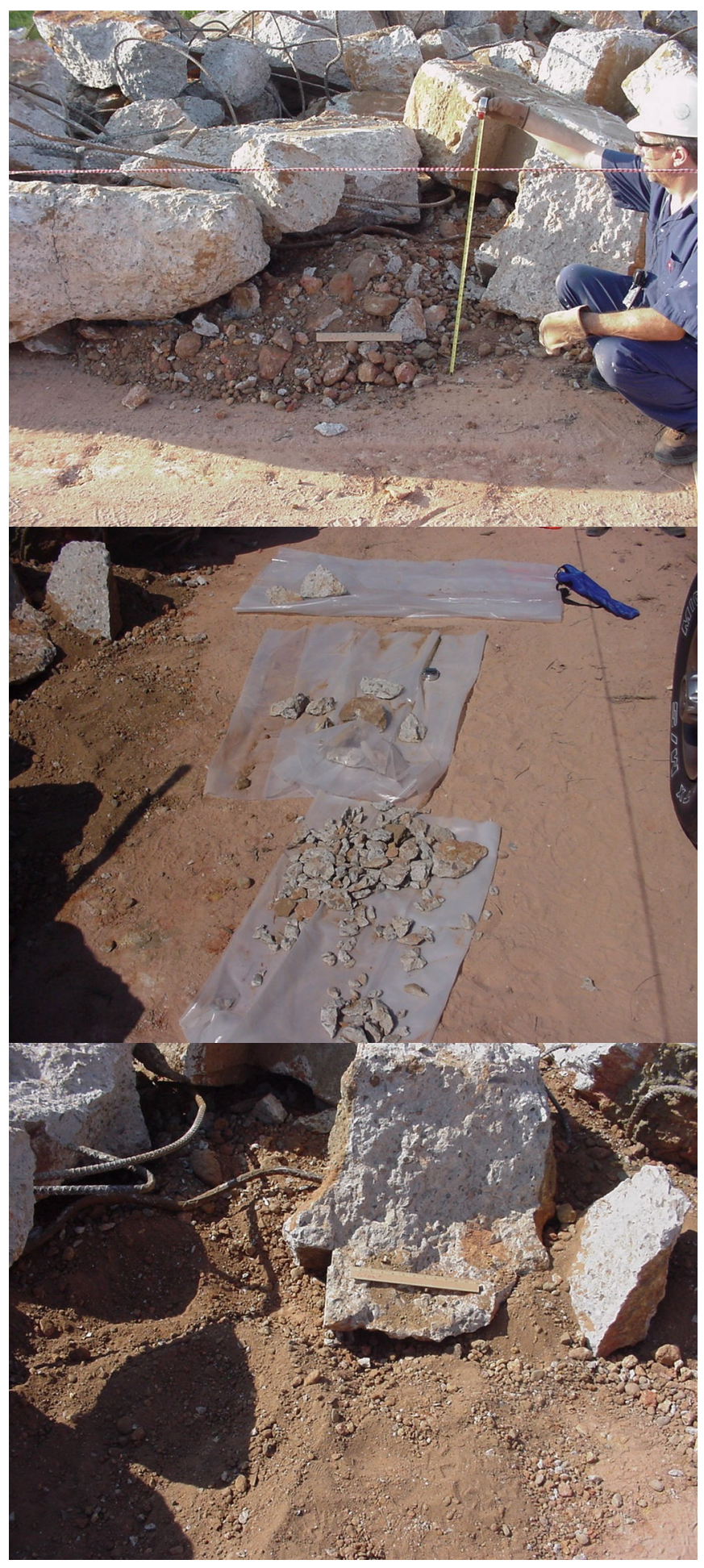

Figure A3. $3 \mathrm{ft} X 3 \mathrm{ft}$ study area before (top) and after (bottom) removing concrete (middle) and soil 

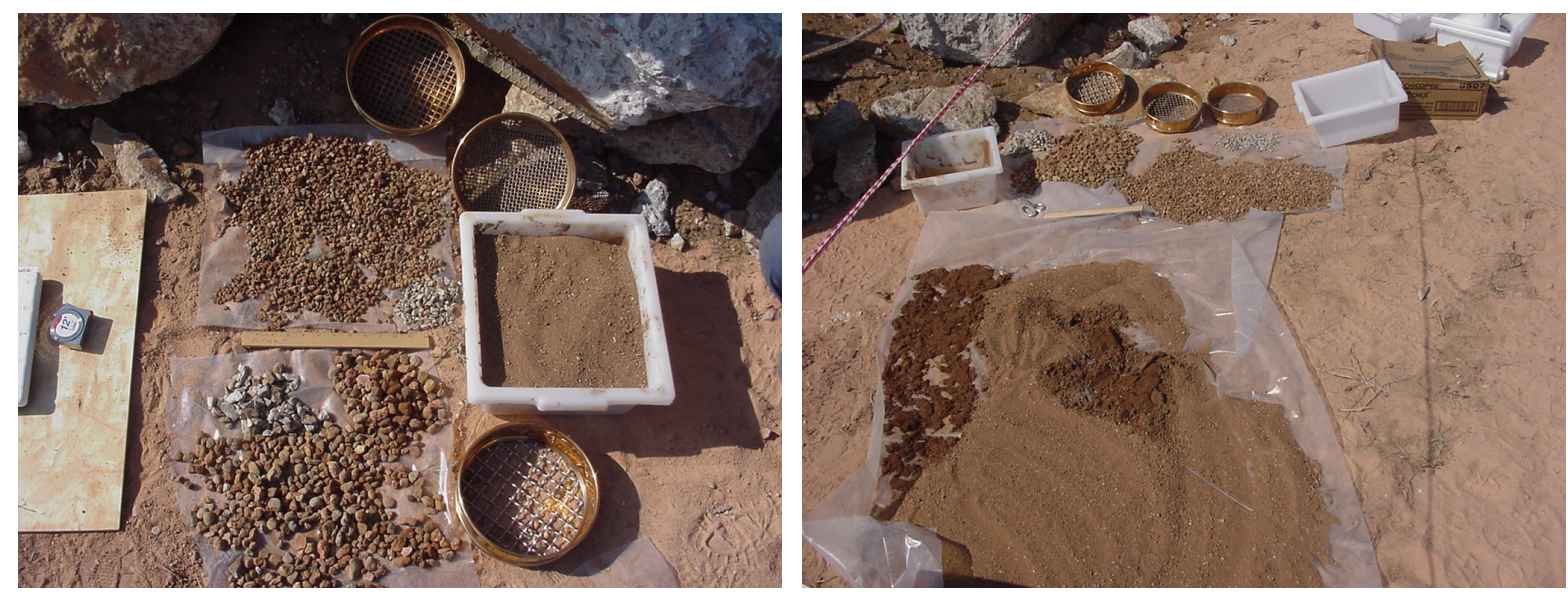

Figure A4. Sieving $<19 \mathrm{~mm}$ mixture of soil and concrete from the $3 \mathrm{ft}$ X $3 \mathrm{ft}$ study area

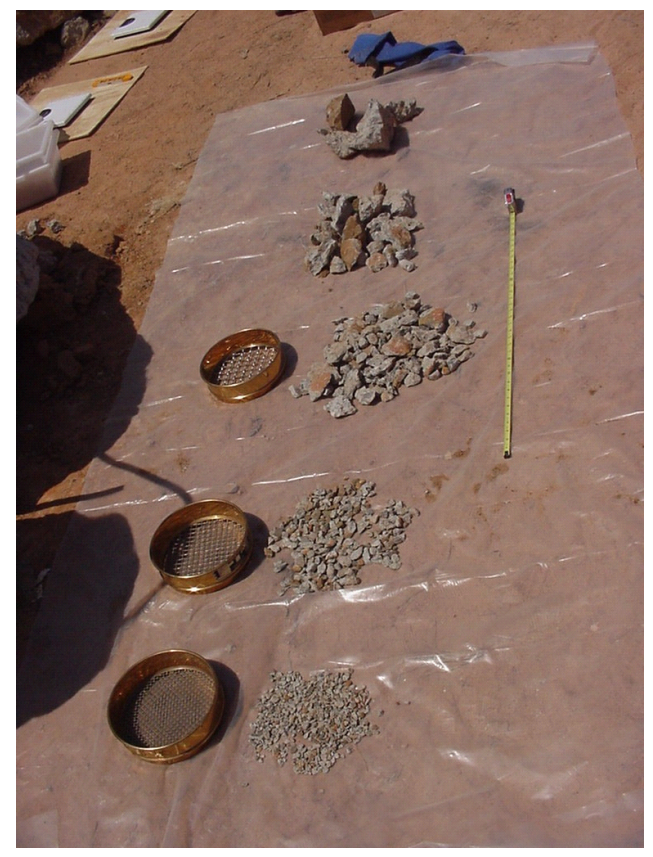

Figure A5. Concrete fractions from the $3 \mathrm{ft} X 3 \mathrm{ft}$ study area. The three largest fractions (upper part of photo) are $>19 \mathrm{~mm}$ and represent the entire $3 \mathrm{ft} \mathrm{X} 3 \mathrm{ft}$ area. The two smallest fractions (lower part of photo) are from sieving $40 \%$ of the $<19 \mathrm{~mm}$ material in the $3 \mathrm{ft} X$ $3 \mathrm{ft}$ study area. 


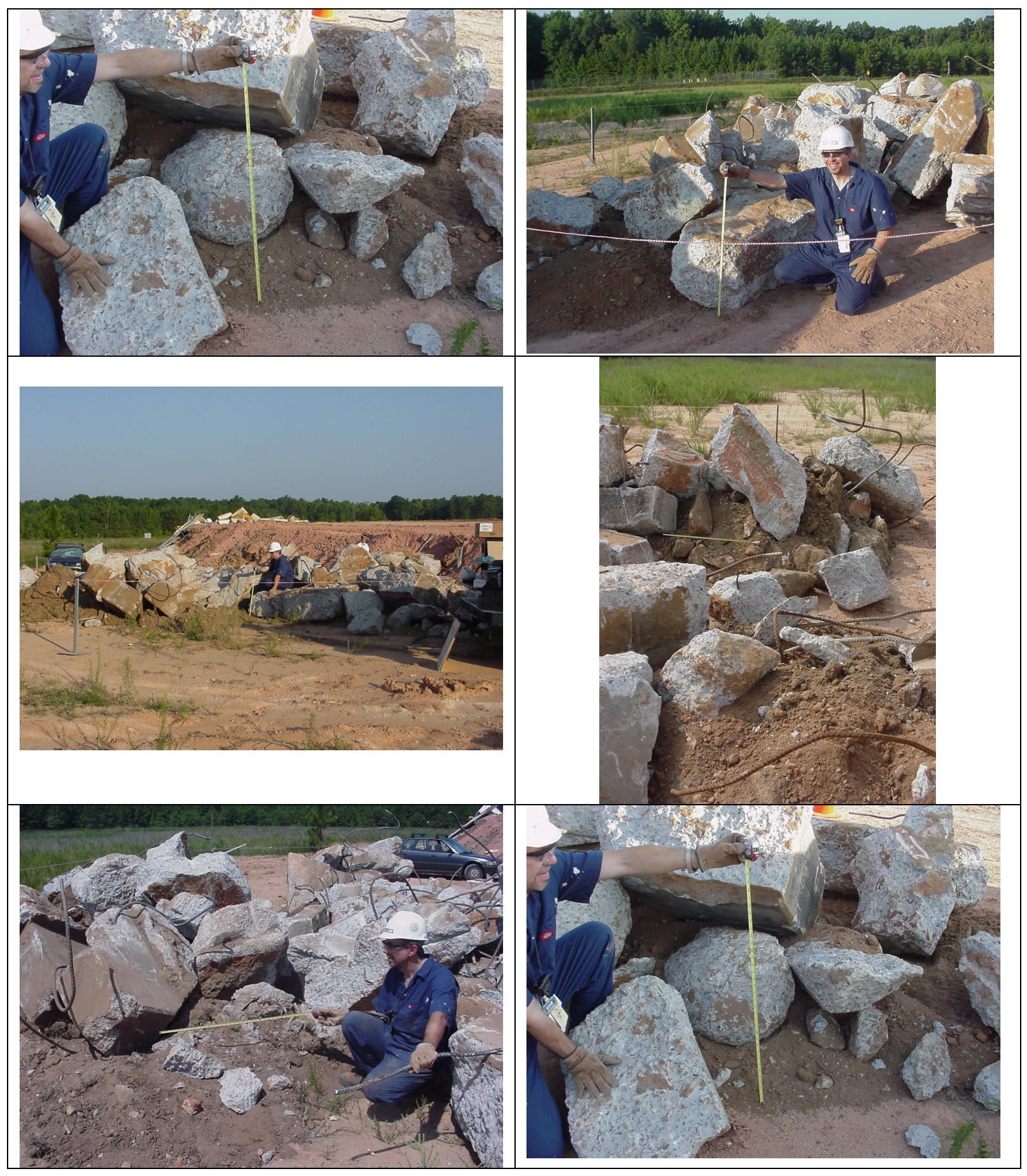

Figure A6. Additional views of the concrete rubble pile. 
WSRC-TR-2004-00215, REV. 0

9.0 APPENDIX B. DESIGN CHECK

Page 26 


\section{DESIGN CHECK INSTRUCTIONS}

Perform a design check for the report, Estimation of Tritium Annual Flux from Concrete Rubble Buried in the E-Area Slit Trenches (U), WSRC-TR-2004-00215, Rev. 0, following the general guidance provided in WSRC-IM-2002-00011, Rev.1.

Specific instructions for this design check are as follows:

1. Check the overall modeling approach to judge if it is reasonable.

2. Check to ensure that the INPUTS are correct for the following:

a. Dimensions of the Slit Trenches shown in Figures 1 and 2 are accurately transcribed into the PorFlow ${ }^{\mathrm{TM}}$ input files.

b. Material and transport properties as shown in Table 1 are accurately transcribed into the PorFlow ${ }^{\mathrm{TM}}$ input files.

c. Spot check PorFlow ${ }^{\mathrm{TM}}$ input files for both flow and transport simulations to make sure that the overall modeling approach is correctly set up.

3. Check to ensure that the OUTPUTS are correct for the following:

a. Spot check mass balance information produced by PORFLOW ${ }^{\mathrm{TM}}$ simulations.

b. Check that the results of the final evaluation as displayed in Figures 7 to 12 correctly represent the output data. 


\section{Design Check By Bob Hiergesell. \\ Black Font: Design Check Instructions \\ Blue Font:" Hiergesell's Response.}

Perform a design check for the report, Estimation of Tritium Annual Flux from Concrete Rubble Buried in the E-Area Slit Trenches (U), WSRC-TR-2004-00215, Rev. 0, following the general guidance provided in WSRC-IM-2002-00011, Rev.1.

Specific instructions for this design check are as follows:

1. Check the overall modeling approach to judge if it is reasonable.

The overall modeling approach was to simulate the flow field enveloping a slit trench, including the native soil, waste zone and clean backfill. This was done with a $2 \mathrm{D}$ cross-sectional model. A flow field was established for each of the 5 representative concrete block sizes, followed by transport simulations to evaluate the tritium fractional flux for each. The output from these simulations was then processed to determine composite fractional fluxes.

The modeling strategy as well as the numerical implementation is judged to be suitable and reasonable.

2. Check to ensure that the INPUTS are correct for the following:

a. Dimensions of the Saltstone shown in Figures 1 and 2 are accurately transcribed into the PorFlow ${ }^{\mathrm{TM}}$ input files.

The dimensions incorporated into the flow and transport simulations for each of the 5 representative concrete block sizes correspond to the dimensions observed in the illustration in Figure 1 (to the degree that precise dimensions could be determined from Figure 1)

b. Material and transport properties as shown in Table 1 are accurately transcribed into the PorFlow ${ }^{\mathrm{TM}}$ input files.

The material properties that appear in Table 1 have been accurately transcribed into the Porflow flow and transport input files. It is recommended, however, that an additional column be added to Table 1 that includes the material and transport properties for Native Soil. Some discussion as to the justification of these specific values would be beneficial.

c. Spot check PorFlow ${ }^{\mathrm{TM}}$ input files for both flow and transport simulations to make sure that the overall modeling approach is correctly set up.

Input files for both flow and transport simulations were examined and appear to be correctly set up.

3. Check to ensure that the OUTPUTS are correct for the following:

a. Spot check mass balance information produced by PORFLOW ${ }^{\mathrm{TM}}$ simulations. 
The mass balances (flux disparities) were very small, having a maximum of $1.15 \mathrm{E}-8$ for the Native Soil in the $2 \times 1$ transport simulation. Most were much smaller than this. This is judged to be acceptable.

b. Check that the results of the final evaluation as displayed in Figures 7 to 12 correctly represent the output data.

Figures 7 - 12 accurately reflect the output data. 